
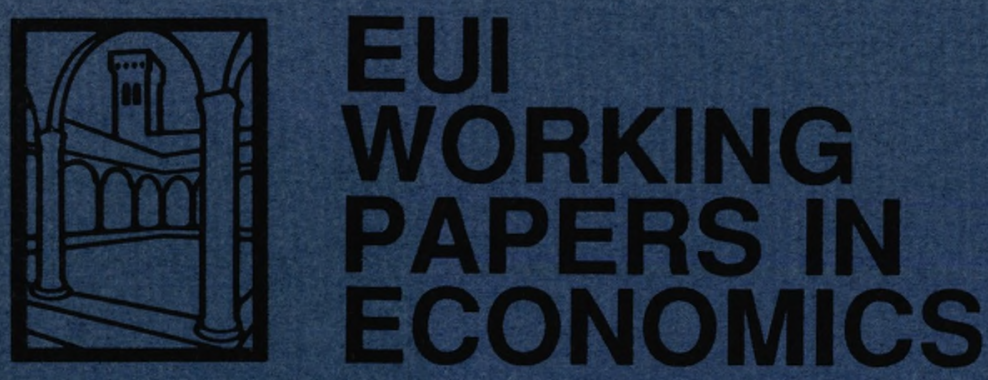

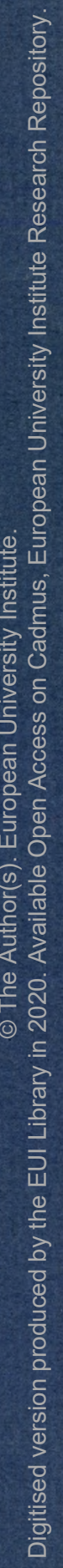

EUR

uropean University Institute, Florence 
European University Library

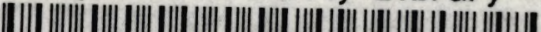




\section{EUROPEAN UNIVERSITY INSTITUTE, FLORENCE ECONOMICS DEPARTMENT}

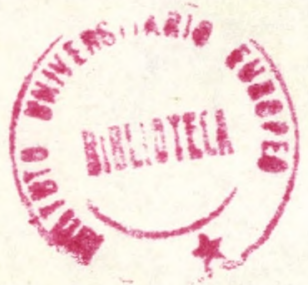

EUI Working Paper ECO No. 90/3

Interpersonal Comparisons of Utility:

Why and how they are and should be made

Peter J. HAMmond

BADIA FIESOLANA, SAN DOMENICO (FI) 
All rights reserved.

No part of this paper may be reproduced in any form without permission of the author.

(C) Peter J. Hammond

Printed in Italy in April 1990

European University Institute

Badia Fiesolana

- 50016 San Domenico (FI) -

Italy 


\title{
INTERPERSONAL COMPARISONS OF UTILITY: WHY AND HOW THEY ARE AND SHOULD BE MADE
}

\author{
Peter J. Hammond \\ Department of Economics, European University Institute, \\ Badia Fiesolana, 50016 S. Domenico (FI), Italy \\ and Stanford University, CA 94305-6072, U.S.A. \\ January 1989; revised August and December 1989.
}

\begin{abstract}
A satisfactory complete normative criterion for individualistic ethical decisionmaking under uncertainty such as Harsanyi's (Journal of Political Economy, 1955) requires a single fundamental utility function for all individuals which is fully interpersonally comparable. The paper discusses reasons why interpersonal comparisons of utility (ICU's) have been eschewed in the past and argues that most existing approaches, both empirical and ethical, to ICU's are flawed. Either they confound facts with values, or they are based on unrealistic hypothetical decisions in an "original position". Instead ICU's need to be recognized for what they really are - preferences for different kinds of people.
\end{abstract}




\section{INTERPERSONAL COMPARISONS OF UTILITY}

...I still believe that it is helpful to speak as if inter-personal comparisons of utility rest upon scientific foundations - that is, upon observation or introspection. .... I still think, when I make interpersonal comparisons ... that my judgments are more like judgments of value than judgments of verifiable fact. Nevertheless, to those of my friends who think differently, I would urge that, in practice, our difference is not very important. They think that propositions based upon the assumption of equality are essentially part of economic science. I think that the assumption of equality comes from outside, and that its justification is more ethical than scientific. But we all agree that it is fitting that such assumptions should be made and their implications explored with the aid of the economist's technique.

- RoBbins (1938, pp. 640-641)

\section{Introduction}

\subsection{Background}

Personal ethics should be about living a good life (cf. Williams, 1985), ethics in public policy about making good public decisions, and ethics in economics about choosing economic policies which improve the allocation of resources. This brings ethics very close to normative decision theory. Indeed, ethics may even become, at one and the same time, both an application and an ideal form of that theory.

Many approaches to ethical decision making have received the attention of moral philosophers and practical people. In my view none is as satisfactory as an idealized form of utilitarianism based upon an ethical concept of utility. Indeed, if one takes an individualistic view of ethics, then utilitarianism can be made virtually tautologous by defining an individual's utility function as that whose expected value ought to be maximized in all the personal matters which affect that individual alone. What is more, utilitarianism itself can be derived from the even more primitive normative principle called "consequentialism". This last principle (Hammond, 1986, 1988a, 1988b) requires that a prescribed norm of behaviour should be explicable solely by its consequences. That is, a "consequentialist" behaviour norm must reveal a "consequence choice function" according to which the consequences of behaviour are chosen from the feasible set of consequences in any decision tree. When the space of consequences is defined broadly enough to accommodate everything of ethical relevance, consequentialism also becomes a tautology 
(cf. Sen, 1987a, p. 40, note 13). Under the conditions spelled out in Hammond (1987a, 1988c) it also implies an idealized form of Harsanyi utilitarianism, based on a single and fully interpersonal comparable "fundamental" utility function for all possible types of individual.

This leaves us with the difficulty of constructing the interpersonally comparable fundamental utility function. Indeed, for many years this has usually been seen as the main problem with Harsanyi utilitarianism in particular. The same is true of Rawlsian maximin, of course, and more generally with the construction of any suitable Bergson social welfare function for use in welfare economics.

Many problems have been created in social choice theory and in welfare economics by the extreme reluctance to mak : any kind of interpersonal comparison of utility (or ICU). The main exception has been the almost certainly unethical comparisons that result from weighing all individuals' dollars equally. Such comparisons emerge implicitly when the "Kaldor-Hicks" compensation principle (actually due to Pareto $(1894,1895)$ and Barone (1908), as explained by Chipman and Moore (1978) and Chipman (1987)) is applied without any actual compensation occurring. They are quite explicit in the aggregate wealth criterion advocated by Strotz (1958, 1961), Harberger (1971) and Posner (1981), and criticized by Fisher and Rothenberg (1961) and by Hammond (1982a). Goldstick (1971) suggested valuing the dollars of those with equal wealth equally, but did not suggest how to compare the dollars of those whose wealth differs.

So great was the reluctance to consider other interpersonal comparisons that it took almost twenty years after the publication of the first edition of Arrow's Social Choice and Individual Values before Sen $(1970 \mathrm{a}, \mathrm{b})$ and others started a systematic study of the implications of relaxing Arrow's most restrictive assumption - namely, the total avoidance of all ICU's in his definition of a "social welfare function." It is true that "independence of irrelevant alternatives" is formulated in a way which excludes interpersonal comparisons (Hildreth, 1953). Nevertheless, it is really the definition of a social welfare function which makes this exclusion almost inevitable and so leads inexorably to a dictatorship (cf. Hammond, 1989). 


\subsection{Coverage}

This paper presents an incomplete yet still quite long survey of that part of the literature on ICU's which seems most relevant to social choice theory and welfare economics. One example of an entirely different approach which I shall not discuss is Wittman (1974) and Nozick's (1985, pp. 166-167) suggestion for using ICU's in criminology in order to compare offenders' punishments with their victims losses, so that sufficient retribution can be exacted.

Nor shall I say much about Shapley's (1969) ingenious proposal, lucidly explained as well as extended by Yaari (1981), and also expounded by Brock (1978b, 1979a, 1980). Shapley suggested constructing a cooperative game of transferable $\lambda$-weighted utility, and determining a weight $\lambda_{i}$ for each individual $i$ so that the utility distribution which emerges in this artificial cooperative game is a feasible distribution in the original game. Yaari's theory only applies when there is a convex set of possible social states. And in applications such as Aumann and Kurz (1977), the theory also presumes the kind of lump-sum redistribution which, as I have argued in Hammond (1979a, 1987b), is generally "incentive incompatible," so not truly feasible. Nevertheless, d'Aspremont (1988) has begun work on extending the idea to Bayesian incentive compatible procedures. See also Keeney and Kirkwood (1975) for related work, and particularly Roth (1980, 1986), Shafer (1980), Scafuri and Yannelis (1984), Aumann $(1985,1986,1987)$ for an intense debate on the significance of the fact that such "NTU value allocations" are often asymmetric.

Another common use of ICU's has been in bargaining theory. Works such as Kalai (1977), Myerson (1977), Neilsen (1983), Kalai and Samet (1985), Bovens (1987) can be consulted in this connection. In effect, bargaining problems represent a very special kind of social decision tree in which a great deal of redistribution is possible. In this and other work, I have chosen to concentrate on social decision procedures which in principle can be applied to a much broader domain of social decision trees.

Finally, yet another important problem neglected here is that of reconciling 
conflicting interpersonal comparisons without either imposition or dictatorship. Arrow mentioned this in his oral discussion of Phelps (1977), and there is some published discussion in Kelly (1978) and Pazner (1979). It has remained a comparatively neglected area. This is in contrast to the very extensive work on "social welfare functionals" (SWFL's) embodying utility information that reflects interpersonal comparisons. I shall have very little to say about SWFL's for two reasons. One is that d'Aspremont (1985) and Sen (1986) have both conducted extensive surveys quite recently. More seriously, however, this literature has never explained precisely where this additional utility information comes from, and that will be my main concern here.

\subsection{Outline}

After this introduction, Section 2 briefly discusses some of the history behind the general reluctance of economists to make ICU's, as well as the impasse which this creates in both welfare economics and social choice theory. Next, Section 3 considers what different forms ICU's may take and distinguishes between interpersonal comparisons of utility levels, and interpersonal comparisons of utility differences. Thereafter Sections 4 and 5 proceed to consider what alternative methods for making such ICU's have been suggested. Section 4 considers the "impersonal" preferences which emerge when individuals are in the hypothetical original position of either Harsanyi or Rawls. Section 5 examines suggestions for inferring interpersonal comparisons from different aspects of individuals' actual behaviour. It seems, however, that such "behaviourist" empirical methods are fundamentally unsatisfactory. I believe thịs is because ethically relevant ICU's are tantamount to normative statements and so cannot be derived just from empirical observation. So finally, in Section 6, a number of explicitly ethical methods of making interpersonal comparisons are considered. In particular, a procedure is put forward for deriving "decision-theoretic" ICU's from a general framework for ethical decision-making, and for integrating such comparisons within that framework by considering the implicit or "revealed" preferences for types of people. Section 7 concludes. 


\section{Social Choice without Interpersonal Comparisons of Utility}

\subsection{Logical Positivism}

In the 1930's, the philosophical doctrine of logical positivism was imported to England from Vienna. Primarily responsible for this, perhaps, was Sir Alfred Ayer, whose Language, Truth and Logic was published in 1936. There he wrote: We can now see why it is impossible to find a criterion for determining the validity of ethical judgements. It is not because they have an 'absolute' validity which is mysteriously independent of ordinary sense-experience, but because they have no objective validity whatsoever ... They are pure expressions of feeling and as such do not come under the category of truth and falsehood. They are unverifiable for the same reason as a cry of pain or a word of command is unverifiable [as a statement] - because they do not express genuine propositions.

- AYER (1936, 1971), p. 144.

As he remarks in Magee (1971), Ayer himself regarded logical positivism as "a blending of the extreme empiricism of Hume with the modern logical techniques developed by people like Bertrand Russell." Even before this, however, in 1932 when Ayer was still only 22, Robbins - perhaps influenced by the Vienna Circle, perhaps not - had published his Essays on the Nature and Significance of Economic Science. The logical positivists saw all ethical statements as "unverifiable" (see Ayer's conversation in Magee, 1971, p.49) - in fact, as just so much noise or exhaust. Actually, Ayer eventually withdrew somewhat from his extreme position - even in the introduction to the second edition of Language, Truth and Logic in 1946 - but we shall return to this later in Section 4. Meanwhile Robbins pointed out that ICU's - at least those of the kind which were used to argue for equality - were also ethical statements of a particular kind which had no scientific foundation. Indeed, Jevons had made a similar claim earlier:

The reader will find again, that there is never, in any single instance, an attempt to compare the amount of feeling in one mind with that in another. I see no means by which such comparison can be accomplished. The susceptibility of one mind may, for what we know, be a thousand times greater than that of another. But provided that the susceptibility was different in a like ratio in all directions, we should never be able to discover the difference. Every mind is thus inscrutable to every other mind, and no common denominator of feeling seems to be possible ...the motive in one mind is weighed only against other motives in the same mind, never against the motives in other minds.

- Jevons $(1871,1970)$ (Introduction - Measurement of Feelings and Motives). 
Cooter and Rappoport (1984) discuss how Fisher (1892) saw that price theory relies only on ordinal utility that is not interpersonally comparable. And Chipman and Moore (1978, p. 548, fn. 2) and Chipman (1987) discuss briefly how Pantaleoni and Barone had persuaded Pareto $(1894$, p. 58) to use the monetary interpersonal comparisons implicit in the compensation principles, before he turned to a general differential form of Bergson social welfare function in Pareto (1913) - see also Bergson (1983).

\subsection{The New Welfare Economics}

Following Robbins, it became fashionable for economists to eschew ICU's, apparently in an attempt to be "scientific". Positive economics, of course, could easily do without them, but even normative economists were swept up by the "new welfare economics" and insisted on limiting themselves to identifying Pareto efficient outcomes, or at least actual or potential Pareto improvements to the existing economic allocation. Without ICU's they could do nothing else. Choosing one Pareto efficient social state over another requires trading off the gains of some individuals against the losses of others. Policy measures which alleviate extreme poverty may be highly desirable, but will not be Pareto improvements if they involve sacrifices by the rich. As Dobb $(1969$, p. 81$)$ points out, this drastic weakness of welfare economics without ICU's had been noted by Harrod (1938) just before the appearance of Robbins' (1938) influential article. Yet the habit has persisted for many years. For instance Archibald $(1959,1965)$ forcefully advocated the view that welfare economists need not proceed beyond identifying changes which everybody desires. And where interpersonal comparisons really have to be made, because the gainers from a change were not going to compensate the losers, the monetary comparisons that result from valuing all individuals' dollars equally still seem to be the most popular among economists, who then wonder why their policy advice does not receive wider acceptance.

On social choice theory without ICU's there is also an enormous literature see, for example, Sen's (1986) recent survey. It is virtually impossible, however, to get any acceptable stronger choice rule than the Pareto criterion of the new welfare 
economics (Sen, 1970a). Indeed, after Arrow's original contribution, not much of this literature seems all that useful in retrospect. The reason is that most of it has tried to circumvent one or other of the conditions of Arrow's impossibility theorem. Elsewhere (Hammond, 1986) I have offered what may seem to be a stronger "consequentialist" defence of these conditions than Arrow and various successors have offered. This suggests that the most important condition of the impossibility theorem is one which was not stated as a formal assumption, though it was clearly expressed as follows:

The viewpoint will be taken here that interpersonal comparison of utilities has no meaning and, in fact, there is no meaning relevant to welfare comparisons in the measurability of individual utility.

- Arrow (1951, 1963, p. 9).

Indeed, Arrow's theorem really is an "impossibility" rather than a "dictatorship" theorem because ultimately even the choice of the dictator requires interpersonal comparisons. And, of course, majority rule attempts to value all individuals' preferences equally, which is another kind of interpersonal comparison.

\section{The Forms of Interpersonal Comparisons}

\subsection{Interpersonal Comparisons of Utility Levels}

Suppose there is a society of individuals $i$ in the finite set $N$, each of whom has a utility function $U^{i}(\cdot)$ which represents $i$ 's personal welfare ordering $R^{i}$ on the domain $X$ of social states. A comparison of utility levels between two individuals $i, j \in N$ is then simply a statement such as $u^{i} \geq u^{j}$, where $u^{i}$ and $u^{j}$ are two particular levels of the utility functions $U^{i}, U^{j}$ for persons $i$ and $j$.

Thus, interpersonal comparions of utility levels (or ICUL's) are simply ordinary comparisons of real numbers. So far, we have not given them any significance, either empirical or ethical. Economists usually give individual utilities empirical significance by considering preferences. Thus the statement

$$
U^{i}(x) \geq U^{i}(y) \Longleftrightarrow x R^{i} y
$$


gives meaning to the ordering of the two utility levels $U^{i}(x)$ and $U^{i}(y)$ for person $i$. But what are we to make of the inequality $U^{i}(x) \geq U^{j}(y)$ when $i \neq j$ ? Person $i$ cannot choose to be person $j$ and person $j$ cannot choose to be person $i$. But person $i$ can want to change places with person $j$, and vice versa, so we might interpret $U^{i}(x)>U^{j}(y)$ to mean that, if $x$ is the social consequence, person $i$ would rather not become person $j$ if $y$ were then the resulting social consequence. Or we can interpret it to mean that, if $y$ has occurred, person $j$ would rather be person $i$ if $x$ were to result. Alternatively, it might mean that a third person $k$ would rather become person $i$ in state $x$ than person $j$ in state $y$.

Whatever their interpretation, it follows that such ICUL's correspond to an interpersonal preference ordering $\tilde{R}$ on the space $X \times N$, so that $U^{i}(x) \geq U^{j}(y)$ if and only if $(x, i) \tilde{R}(y, j)$. Notice that, as in Suppes (1966), different individuals $k$ in $N$ will usually have their own interpersonal orderings $\tilde{R}^{k}$ on $X \times N$; there is no guarantee that they will have the same estimate of what it means in welfare terms to be another person. Indeed, different individuals $k$ can even have their own personal opinions of what constitutes the utilities of individuals $i$ and $j$, so that we really need to write

$$
U^{i k}(x) \geq U^{j k}(y) \Longleftrightarrow(x, i) \tilde{R}^{k}(y, j)
$$

where $U^{i k}(\cdot), U^{j k}(\cdot)$ denote $k$ 's assessments of the utility functions of $i$ and $j$ respectively.

However, as both Harsanyi (1955) and Sen (1970a) discuss at some length, it is usual to assume that the different individuals $k$ in $N$ can at least agree on what constitutes the welfare orderings of person $i$ and person $j$. It is not at all clear to me that this is a very good assumption, but it may be all right if we suppose that each individual $i$ is closely consulted on what makes up his utility, and each other individual $k$ uses this information. This is the axiom of identity. Then the interpersonal ordering of each individual $k \in N$ must respect the welfare orderings of other individuals, so that, for all $i, k, x, y$, one has

$$
(x, i) \tilde{R}^{k}(y, i) \Longleftrightarrow U^{i k}(x) \geq U^{i k}(y) .
$$


It follows that each $U^{i k}(x) \equiv \phi^{i k}\left[U^{i}(x)\right]$, where $\phi^{i k}$ is an increasing transformation of $i$ 's personal utility function. The ICUL's become comparisons of different individuals' indifference curves. Nevertheless, in future the possible dependence of ICU's on $k$ will be ignored throughout.

The question of what it means to want to be another person has still not really been faced, however, as it must be if this approach to ICUL's is to have proper empirical significance. I shall return to this later in Sections 4, 5 and 6. For the moment, assuming that ICUL's do have ethical significance, we ask what kind of ethical significance are they likely to have.

If $U^{i}(x)>U^{j}(x)$, the presumption has generally been that an egalitarian, who will tend to favour equalizing utility levels if possible, will want to try to alter social state $x$ somewhat in order to increase person $j$ 's utility, perhaps by a transfer of income from $i$ to $j$, even if this may mean lowering person $i$ 's utility (cf. Sen, 1973). How much the egalitarian is prepared to sacrifice $i$ 's utility in order to increase $j$ 's remains unclear, however. Indeed, if it is possible to increase $i$ 's utility a lot by moving away from state $x$, even though this means decreasing $j$ 's utility, a mild egalitarian may even be prepared to accept this inegalitarian change. Of course, these considerations really only make sense if intensities or differences in utility can be compared interpersonally, as well as levels.

An extreme egalitarian would presumably see $U^{i}(x)>U^{j}(x)$ as justifying any change which promoted $j$ 's welfare, even at the expense of $i$, provided it did not go so far as to make $i$ even worse off than $j$ was in state $x$. In other words, if $U^{i}(x), U^{i}(y)$, and $U^{j}(y)$ all exceed $U^{j}(x)$, and if all other individuals are indifferent between $x$ and $y$, then $y$ should be socially preferred to $x$. This is exactly the equity axiom and the two-person leximin rule discussed in Hammond (1976a, 1979b) and Sen (1977). Under the conditions of unrestricted domain and independence of irrelevant alternatives, as well as Pareto indifference, it becomes equivalent to the leximin criterion of Sen (1970a). This form of extreme egalitarianism is also related to Strasnick's $(1976 \mathrm{a}, 1976 \mathrm{~b}, 1977,1979)$ idea of "preference priority." Under this idea, for each pair of individuals $i, j \in N$ and each pair of alternatives $x, y, \in X$, 
we say that $i$ 's preference for $x$ over $y$ takes priority over $j$ 's preference for $y$ over $x$ if $x P y$ when $x P^{i} y, y P^{j} x$, and all other individuals are indifferent between $x$ and $y$.

Such extreme egalitarianism is ethically unappealing because, when $U^{i}(x)$ is much bigger than $U^{j}(x)$, it may prescribe very large sacrifices in $i$ 's welfare even when the gains to person $j$ are extremely small. Such arguments rest, however, on being able to compare $i$ 's losses with $j$ 's gains, and this is a different kind of interpersonal comparison which I shall come to consider in a moment. It should be noted, however, that the ethical significance of ICUL's on their own remains somewhat unclear in this framework, unless we do accept extreme egalitarianism and so Rawls' difference principle. Of con se, ICUL's do allow egalitarian allocations to be identified in economic models with a sufficiently rich feasible set from which to choose, as in Dworkin (1981), Roemer (1985), Cohen (1989), and other related bargaining models. They do not, however, tell us how to compare different inegalitarian allocations, or even how to compare egalitarian allocations with inegalitarian ones.

\subsection{Interpersonal Comparisons of Utility Units or Differences}

Interpersonal comparisons of utility differences (or ICUD's) amount to comparisons of the form $u_{1}^{i}-u_{2}^{i}>u_{1}^{j}-u_{2}^{j}$, where $u_{1}^{i}, u_{2}^{i}$ are two levels of person $i$ 's utility function, and $u_{1}^{j}, u_{2}^{j}$ are two levels of person $j$ 's utility function. What then is the empirical significance of a statement such as

$$
U^{i}(x)-U^{i}(y)>U^{j}(w)-U^{j}(z) ?
$$

Insofar as $U^{i}(x)-U^{i}(y)$ measures the "preference intensity" of person $i$ for $x$ over $y$, and $U^{j}(w)-U^{j}(z)$ the "preference intensity" of person $j$ for $w$ over $z$, this seems to be just a straightforward comparison of preference intensities. But what empirical significance do we attach to a person's "preference intensity", and on what empirical basis do we "compare" the preference intensities of different people? Some suggestions for answers to both these questions are discussed in Section 5 , but none are very satisfactory. 
At its face value, (5) means something like preferring moving from state $y$ to state $x$ if one is person $i$ to moving from state $z$ to state $w$ if one is person $j$. This is hardly an operational preference, however. But suppose $w=y$ and $z=x$, so that (5) becomes

$$
U^{i}(x)-U^{i}(y)>U^{j}(y)-U^{j}(x)
$$

This means that moving $i$ from $y$ to $x$ is preferable to the reverse move of $j$ from $x$ to $y$. It suggests that, if we are only considering what happens to persons $i$ and $j$, then we should prefer $x$ to $y$ because $i$ 's gain outweighs $j$ 's loss. As an empirical statement, this means very little indeed, but as an ethical statement, its immediate implications seem rather clear at first sight.

Even as an ethical statement, however, we may not always want to infer from (6) that $x$ should be preferred to $y$ if we take account only of persons $i$ and $j$. Consider the following possibility, of the kind discussed by Sen (1973). Although $U^{i}(x)-U^{i}(y)$ may be greater than $U^{j}(y)-U^{j}(x)$, it may also be true that $U^{i}(x)>U^{i}(y)>U^{j}(y)>U^{j}(x)$ and that actually $U^{i}(y)$ may be very much greater than $U^{j}(y)$. Of course, this amounts to an ICUL. It suggests, however, that we should try to increase $j$ 's welfare on egalitarian grounds, even if this has to be done at the expense of $i$. Moving from $x$ to $y$, as suggested on the basis of ICUD's, is therefore inegalitarian when one judges on the basis of ICUL's.

With both types of comparison, one has "dual" comparisons of the kind considered in Hammond (1977), and there will usually be tensions between the ethical prescriptions suggested by the two different types of comparison. Such tensions seem hard to avoid in general social choice problems although, as shown in that paper, the two types of comparison could be reconciled sometimes when the problem is to choose a first-best optimal income distribution (in the absence of any incentive constraints). Basically, when both $U^{i}(x)-U^{i}(y)>U^{j}(y)-U^{j}(x)$ and $U^{i}(x)>U^{i}(y)>U^{j}(y)>U^{j}(x)$, there has to be a judgment of whether the excess of $i$ 's gain over $j$ 's loss is more than enough to outweigh the inegalitarian results of the move from $y$ to $x$. These are the kind of questions which are difficult to 
resolve without a single coherent decision framework in which ICU's can both be made and used in ethical decisions. For this reason I regret that the discussion of Hammond $(1977,1980)$ now seems largely irrelevant.

Having discussed the form of ICU's, it is now time to consider their meaning.

\section{Impersonality and Fundamental Preferences}

In the first edition of Language, Truth and Logic I had maintained that propositions about oneself, one's own feelings, were to be taken at their face value, so that when I was talking about my own thoughts I was talking about thoughts, feelings and so on, but that propositions about the mental states of other people were propositions about their behaviour. This was a fairly natural deduction from the principle of verifiability, but I came to see that it was wrong and in fact even inconsistent, that it could be shown to lead to a contradiction, and these two classes of propositions had to be taken symmetrically. And once you take the view that they have to be symmetrical then either ou can treat yourself behaviouristically, which means, as Ogden and Richards once put it, feigning anaesthesia, or you can ascribe thoughts and feelings to others in the literal way in which one ascribes them to oneself.

- Ayer, in Magee (1971) PP. 54-5.

"Impersonality" is the term used by Harsanyi (1953b, 1955) to describe the idea that, in order to free oneself from an unduly selfish perspective in weighing moral issues, an ethical observer should pretend to be completely uncertain which individual he will become after the issue is decided. In this formulation of utilitarianism, therefore, individuals are meant to choose as though behind a "veil of ignorance" - to borrow Rawls' (1971) felicitous term - uncertain what positions they will eventually occupy in the society being affected by the decisions under consideration. This Kantian idea is similar to Hare's $(1951,1963)$ principle of "universalizability", under which any person should only prescribe what he would still be willing to prescribe even if he were somebody else completely. And it is perhaps even close in spirit to what Rawls describes as "the original position" see Rawls (1959, 1971).

Harsanyi and Rawls both use this concept of impersonality or the original position in order to arrive at alternative specific forms of social ordering. Harsanyi assumes that a person who acts as though he does not yet know who he is will be "Bayesian rational" and maximize the expected utility of a von NeumannMorgenstern utility function, giving equal probability to becoming each possible 
individual in the society. Rawls, on the other hand, hypothesizes a much less orthodox view of behaviour under uncertainty in the original position, which focuses upon the person who one would least like to be. This leads to his "difference principle." If one restricts oneself to a utilitarian framework (which Rawls does not), this would suggest maximizing the minimum utility level - i.e., maximin. This could conceivably be an acceptable ethical criterion if one lived in a world where the only risk is in the original position. Where individual consequences are risky, however, rules like maximin violate the independence axiom, as Harsanyi (1975a, b, 1977b, 1978) pointed out. In fact, as Lyons (1972), Arrow (1973), Gordon (1973), and in particular Barry (1973) have discussed with some care, Rawls' defence of the difference principle is not at all convincing. Harsanyi's defences of his version of the original position are possibly rather better argued, but much controversy still surrounds them. For this reason, one of my aims in Hammond (1987a) was precisely to avoid any arguments based upon an original position or a veil of ignorance. The main idea will now be recapitulated.

Indeed, to go beyond ICUL's we can follow Harsanyi's idea of considering lotteries to get ICUD's as well. Thus let $\Theta$ denote the set of all possible individual characteristics. Let $\Delta(X \times \Theta)$ denote the set of all simple probability measures or lotteries (with finite support) on $X \times \Theta$. Each measure $\mu$ in $\Delta(X \times \Theta)$ is a finite collection of possible threesomes $\left(x_{k}, \theta_{k}, p_{k}\right)$ consisting of a social state $x_{k}$ and a personal characteristic $\theta_{k}$, together with the non-negative probability $p_{k}$ that $\left(x_{k}, \theta_{k}\right)$ will occur. Of course, $\sum_{k} p_{k}=1$. Suppose that the ethical observer imagines himself facing decision trees with random consequences in the space $\Delta(X \times \Theta)$ of such lotteries. Such decision trees include but are not restricted to those in which decisions must be taken behind a veil of ignorance. Then, provided that the observer recommends behaviour which is (with probability one) both dynamically consistent in each possible decision tree, and also depends only on the consequences of his choices, then he must maximize some preference ordering over this space of lotteries which satisfies the independence axiom. If one also imposes a rather weak continuity condition on behaviour, it can also be shown 
that all three axioms of Herstein and Milnor (1953) are satisfied (see Hammond, 1983, 1987a and 1988a, b). Therefore the observer must maximize the expected value of some von Neumann-Morgenstern utility function (or NMUF) which I shall write as $u(x, \theta)$.

Note that the resulting "fundamental" utility function contains within it interpersonal comparisons of both utility levels and utility differences. For the ICUL $u\left(x, \theta_{i}\right)>u\left(y, \theta_{j}\right)$ can be taken to mean that the ethical observer prefers to be a $\theta_{i}$-person in state $x$ rather than a $\theta_{j}$-person in state $y$. And the ICUD $u\left(x, \theta_{i}\right)-u\left(y, \theta_{i}\right)>u\left(z, \theta_{j}\right)-u\left(w, \theta_{j}\right)$ can be taken to mean that the ethical observer prefers a $50-50$ lottery with $\left(x, \theta_{i}\right)$ and $\left(w, \theta_{j}\right)$ as possible outcomes to one with $\left(y, \theta_{i}\right)$ and $\left(z, \theta_{j}\right)$ as possible outcomıs.

Two special cases deserve to be mentioned. Rawlsian ICUL's alone emerge when one excludes lotteries altogether and simply chooses between sure pairs in $X \times \Theta$. Harsanyi's ICUD's alone emerge when one restricts attention to lotteries in which the probabilities of different social states $x$ are independent of the probability distribution over $\theta$, and when the latter corresponds to the actual distribution of personal characteristics in the population under consideration, as in Harsanyi's version of the original position.

Such impersonal preferences may have a superficial appeal in seeming to fit what we perhaps think of when we make ICU's. The empirical basis of the ICU's which result, however, is not very strong, unless we find a lot of people who are used to thinking in this precise impersonal way, and ask them their views. Nor are their ethical implications all that clear, since we still have to construct a social ordering based on such ICU's, and there are many possibilities, as Roberts (1980a, b), Blackorby, Donaldson and Weymark (1984), d'Aspremont (1985) and Sen (1986), for instance, have all discussed. This problem is by no means limited to "impersonal" ICU's, however, though we may be able to circumvent it by considering ethical ICU's directly, as in Section 6 below. 


\section{Behaviourist Approaches}

\subsection{Introduction}

It would seem empirically ideal if we were able to base ICU's on personal behaviour. Not surprisingly, therefore, there have been many attempts to do so. Yet one can see straight away that this is unlikely to succeed completely, in as much as different ethical observers are likely to find different behaviourist criteria more appealing.

Let me nevertheless consider some of the behaviourist approaches which have been proposed. To do so, it will be convenient to consider two rather different aspects of these behaviourist approaches separately. The first concerns the construction of a cardinal utility function to represent each individual's preferences, which is clearly necessary if one is to make ICUD's. The second aspect is the comparison of different individual's utility functions as such, once they have been cardinalized.

\subsection{Preference Intensities}

The most common suggestion for cardinalizing individual utility functions before comparing their differences interpersonally is to use NMUF's. These are assumed to describe each individual's personal attitudes towards risk. Relative differences of utility are taken as measures of preference intensity for a single individual. I have already discussed this procedure at some length in Hammond (1982b, 1983, 1987a). I find it more compelling than many other approaches, but not all that compelling. Initially, its chief advocates, apart from Harsanyi (whose arguments are rather different anyway), were Vickrey $(1945,1960)$ and Jeffrey (1971). Its many critics have included Friedman and Savage (1948, 1952), Arrow (1951), Diamond (1967), Sen (1970a, 1973) and, of course, Rawls (1971). A general discussion of this and other kinds of intensity approach can also be found in Weirich $(1983,1984)$.

One apparent source of confusion should be cleared up at once. It has been argued by some, and is hinted at by Arrow (1951), that using NMUF's to cardi- 
nalize is unacceptable when there is no risk, but quite acceptable when there is risk. Yet this leads to a discontinuity. If the NMUF cardinalization is right for risky prospects then it is right, presumably, for a sequence of risky prospects which converges to a sure prospect. Why then is this same cardinalization not right in the limit, when we converge to a sure prospect? Instead, I prefer to regard the usual NMUF cardinalization as being inappropriate for ICU's in all situations, be they risky or sure.

Of course, even if one accepts the NMUF cardinalization of individual utilities, that does not yet make them interpersonally comparable. To do so, Isbell (1959) had an ingenious suggestion. To avoid St. Petersburg-like paradoxes, one can argue that each individual $i$ must have an NMUF $v_{i}$ which is bounded both above and below. Otherwise, as Menger (1934) and Arrow (1972) showed, there are discontinuities in preferences for some sequence of probability distributions which converges in the limit to a distribution which attaches positive probability to an infinite sequence of consequences. Then Isbell suggested normalizing each individual's utility function by an affine transformation which puts equal upper and lower bounds on all individuals' utilities - e.g., a lower bound of 0 , and an upper bound of 1 . Summing normalized utilities then gives a well defined social ordering. So does a similar normalization procedure suggested by Schick (1971) and criticized by Jeffrey (1974). The ethical appeal of equating different person's upper and lower bounds remains unconvincing, however, at least to me. Consider some undemanding person who achieves his upper bound at a low level of consumption. Do we normalize that person's utility scale so that it has the same upper and lower bounds as that of a greedy person? If so, and if we distribute goods to each individuals so that each achieves, say, $90 \%$ of maximum utility (which is now a well defined utility level), then the greedy person is likely to be given much more than one feels he deserves.

Most other cardinalizations also rest more or less on some way of trying to infer the intensities of an individual's preferences from personal behaviour. One prominent method is the use of "just noticeable differences". This derives from Edge- 
worth(1881). It is assumed that each individual has a preference semi-ordering of the kind formalized by Luce (1956), in which a transitive indifference relation is replaced by an intransitive incomparability relation. Then, under certain additional assumptions such as those presented by Suppes and Winet (1955) and Kaneko (1984), there exists a utility function $U^{i}(\cdot)$ for each individual $i$ and a positive number $\delta^{i}$ such that

$$
x P^{i} y \Longleftrightarrow U^{i}(x)-U^{i}(y)>\delta^{i} .
$$

Evidently, such inequalities enable intrapersonal comparisons of utility differences and so a cardinalization. Normalizing each individual's utility function $U^{i}$ by multiplying the function by the constant $1 / \delta^{i}$, it can even be arranged that all the $\delta^{i}$ 's are equal to one, which Goodman and Markovitz (1952) and more recently $\mathrm{Ng}(1975,1984 \mathrm{~b}, 1985 \mathrm{~b})$ have used to make ICUD's. Svensson (1985) and others have raised obvious objections to adding individuals' utilities that have been cardinalized in this way. But such ICUD's themselves are ethically unattractive, as Arrow (1963, pp. 115-8) for one has argued. This is because they tend to favour the sensitive or those who are most able to complete their indifference map. If we think about income distribution impersonally, for instance, do we believe that we would value income more if our personal characteristics became those of a person who noticed more differences in his utility ranking? And even if we confine ourselves to intrapersonal comparisons, does it really make sense to value an income change half as much just because it moves a person through half as many just noticeable differences? The fundamental problem is that the relationship of just noticeable differences to idealized ethical decisions is tenuous at best. As Arrow also points out, the same is true of Dahl's (1956) suggestion of using willingness to incur enough trouble to vote for $x$ over $y$ as an indication that intensity of preference is sufficient to make voting worthwhile.

A proposal which is somewhat related is to cardinalize utility by looking at the probability that the person chooses $x$ over $y$. It is assumed, of course, that this probability may not be unity even when $x$ is better than $y$. Instead, we 
have probabilistic choice models of the kind considered by psychologists such as Luce (1959) and reviewed in Becker, DeGroot and Marschak (1963) (see Edwards and Tversky, 1967) using such probabilities of choice, but over the whole domain of options. Intriligator (1973) equated "utilities" with probabilities of choice, in effect. A related suggestion is due to Waldner (1972), who suggests that if possible one should construct a utility function for each individual so that the probability of choosing $x$ over $y$ is an increasing function of $U^{i}(x)-U^{i}(y)$ (e.g., as in a probit econometric equation - see Amemiya, 1981). Alternatively, the "latency" of choice - the time it takes for the person to decide for $x$ over $y$ - could be assumed to be some function of $U^{i}(x)-U^{i}(y)$. And, in a later paper, Waldner (1974a) combines the ideas of probabilisti choice with just noticeable differences by looking for "bare preferences", defined so that " $x$ is barely preferred to $y$ " means that $x$ is chosen over $y$ with probability 0.75 (see also Becker 1974 and Waldner 1974b).

Now, it may be that we can get a good measure of an individual's utility by the looking at the right hand side exogenous variables of some probit (or logit) econometric equation, which is what this kind of procedure would seem to lead to eventually. Yet I remain unconvinced. For, bearing in mind that an individual's "utility" should surely be based on idealized choices, I have to ask why such superficial irrationalities as imperfect discrimination and the failure to choose the best with probability one should have any ethical relevance at all.

\subsection{Social Indicators}

Two entirely different suggestions for cardinalizing individual utilities, as well for comparing the cardinalized utilities interpersonally, are contained in the article by Simon (1974) — with comments by Toharia (1978) and a reply by Simon (1978) - and also in the "Leyden" approach of van Praag and his associates see van Praag (1968, 1971), van Praag and Kapteyn (1973), Kapteyn and van Praag (1976), Kapteyn (1977), van Herwaarden, Kapteyn and van Praag (1977), Tinbergen (1980, 1985, 1987a, b), Hagenaars (1986), van Praag and van der Saar (1988), and especially Seidl's (1987) careful review of Hagenaars' monograph. 
Simon lists a number of aspects of individual behaviour which are correlated with personal income and so, Simon claims, might be used to construct a measure of welfare. They include the propensity to commit suicide on the one hand or murder on the other (both negatively correlated with income), statements about how happy a person feels, and also different aspects of personal health - how well the person thinks he is, worries, psychological anxiety, severe mental illness, etc. Some economic variables which he also considers include a function defining the utility of consumption for each time period, which would be a cardinal utility function if preferences over consumption streams were additively separable, which almost certainly they are not.

A second economic variable Simon considers is labour supply, based on the observation by Kindleberger (1965) that hours worked per week in manufacturing industry are higher in countries with lower incomes per head. Even as some measure of "national" utility, however, this measure seems extremely suspect; as a measure of individual utility, it is clearly useless, since it would suggest that the unemployed are the best off of all! As for Simon's other measures, do we really want to say that extra money means most to an individual whose propensity to commit suicide or to fall ill is thereby most reduced? Or even to say that it means most to an identifiable group of individuals whose collective propensity to commit suicide or to fall ill is thereby most reduced? And even if we do, what is the appropriate cardinalization of utility based on such propensities?

The Leyden approach of van Praag and his associates uses a different technique. This involves constructing a "social indicator" of well-being - as discussed by sociologists such as Levy and Guttman (1975) or McKennell (1978) - supplemented, however, by explicit interpersonal comparisons of such social indicators. The construction is based on the intervals of net family income levels which each individual in a sample reports as being necessary to achieve an income which is "excellent", or "good", or "barely sufficient", or "bad" - in fact, they use up to nine different quality descriptions. They rank the eight different boundaries between quality intervals on a scale from 0 to 1 , and then fit a lognormal cumulative 
probability distribution function to these reports. The result is taken as the "individual welfare function of income". Different types of individuals are characterized by the mean and the standard deviation of the distribution of the logarithm of income which best fits their reports. They find that the mean is positively related to income and to family size, while the standard deviation increases for people whose incomes have fluctuated in the past, or whose "social reference group" consists of people with widely differing income levels. Thus, the utility of income function for a particular group of people is a smoothing of the function obtained by looking at the proportions of people who regard any particular income level as "good", "sufficient", "bad", etc. The smoothing occurs, as explained above, by fitting a cumulative lognormal distribution. Reasons for choosing this distribution are especially unclear, as Seidl (1987) also points out.

This is an ingenious device very similar to that suggested by Rescher (1967, 1969) for more general decisions than the choice of income distribution. But it faces a number of questions concerning the significance of the findings - particularly their ethical significance. If one only thinks how one would oneself go about completing the questionnaire which these researchers used, one begins to realize that the survey results must be based on extremely tenuous foundations. The questionnaire actually seems harder to fill in, moreover, when one realizes that the results will be used to construct a cardinalized utility function in order to decide what is an appropriate income distribution. Unless, that is, one has some confidence already in what is the right cardinalization. The approach also faces considerable problems when one tries, as van Praag (1968) and also Kapteyn (1977) indeed did, to go beyond a purely one good framework and allow different consumers to have different tastes for many consumption goods. If there were public goods as well, the method would be very stretched indeed.

It therefore seems to me that there has not yet emerged any thoroughly satisfactory behaviourist approach to cardinalizing individual utility functions. The fact that so many different approaches have been tried, all of which have some merits but also some serious faults, suggests that even at this level we cannot 
overcome "Hume's Law", which claims that one cannot derive an "ought" from an "is". Indeed, in Hume's own words:

In every system of morality, which I have hitherto met with, I have always remark'd, that the author proceeds for some time in the ordinary way of reasoning, and establishes the being of a God, or makes observations concerning human affairs; when of a sudden I am surpriz'd to find, that instead of the usual copulations of propositions, is, and is not, I meet with no proposition that is not connected with an ought, or an ought not. This change is imperceptible; but is, however, of the last consequence. For as this ought, or ought not, expresses some new relation or affirmation, 'tis necessary that it shou'd be observ'd and explain'd; and at the same time that a reason should be given, for what seems altogether inconceivable, how this new relation can be a deduction from others, which are entirely different from it. But as authors do not commonly use this precaution, I shall presume to recommend it to the readers; and am persuaded, that this small attention wou'd subvert all the vulgar systems of morality, and let us see, that the distinction of vice and virtue is not founded merely on the relations of objects, nor is perceiv'd by reason.

- Hume (1739-40; 1969, p. 521).

As Hume foresaw, there is just no way we can use empirical observations on their own to produce an ethically satisfactory cardinalization, let alone an ethically satisfactory social welfare ordering. As Samuelson (1937, p. 161) put it more than fifty years ago:

in conclusion, any connection between utility as discussed here and any welfare concept is disavowed. The idea that the results of such a statistical investigation could have any influence upon ethical judgment of policy is one which deserves the impatience of modern economists.

\subsection{Fundamental Preferences and Isomorphy}

All men are born equal: it's their habits that make them different.

\section{- (attributed to Confucius).}

The idea that, deep down, we are really all alike, is rather an old one in moral philosophy. And it would be helpful particularly in making interpersonal comparisons of utility levels if there were a universally accepted preference ordering on the space which everybody shares. Then the comparison $\left(x, \theta_{1}\right) \tilde{R}\left(y, \theta_{2}\right)$ would mean that everybody weakly prefers being in state $x$ with characteristics $\theta_{1}$ to being in state $y$ with characteristics $\theta_{2}$. Among economists, an ordering of this kind has been postulated by Tinbergen (1957) and Kolm (1972). Under standard assumptions, it gives rise to a utility function $u(x, \theta)$ which enables ICUL's to be 
made. The utility still needs cardinalization, however, if we are to compare utility differences as well. This is what Harsanyi (1955) tried to provide.

Such "fundamental preferences," as Kolm calls them, make especial sense when we recognize that individuals do not have fixed characteristics, and so find themselves choosing what characteristics to have as well as making the usual economic and other decisions. This is the topic of Section 5.5 below. Unfortunately, it is by no means clear why a universally accepted interpersonal preference ordering should emerge, as MacKay (1986), for one, discusses.

An alternative rather less general approach is that of "isomorphy", to use Mirrlees' (1982) term. A general formulation of this principle is found in Arrow (1977); it is related to the Gorman $(1956,1980)$ and Lancaster (1966) "characteristics" approach to consumer demand theory. A similar approach is also used by Stigler and Becker (1977) to construct what is in effect a fundamental utility function shared by all, though they do not care to use the function to make interpersonal comparisons. There is a space $Z$ of "characteristics" such that, for each consequence $y$ in $Y$ and each individual $i$ in $N$, there is a characteristic vector $G_{i}(y)$ in $Z$ which describes the effect of $y$ on $i$. Each $z$ in $Z$ is supposed to include not only Gorman-Lancaster characteristics but, in some cases, tastes too (Arrow, 1977). Then there is a utility function $u$ on $Z$ which is the same for each individual. A similar but simpler version is discussed by Mirrlees (1982), who assumes that individuals differ only in their skill level $n$, and that each individual has the same utility function $u(x, y / n)$ where $x$ is consumption and $y$ is output in efficiency units from the labour which the individual supplies. Yet another kind of "isomorphy" arises in connection with family equivalence scales. These were as introduced by Barten (1964), then used by Muellbauer (1974a, b, c, 1975, 1977) especially in order to make interfamily comparisons of utility levels. Such comparisons have been criticized by Pollak and Wales (1979) - see also Muellbauer (1987), Blackorby and Donaldson (1987). For these family equivalence scales it is assumed that each household has a utility function for consumption vectors of the form $u\left(x_{1} / m_{1}, x_{2} / m_{2}, \ldots, x_{n} / m_{n}\right)$, where $x_{g}$ denotes family consumption 
of good $g$, and $m_{g}$ is a scaling factor for good $g$ which depends on family composition. These scaling factors can be derived from demand data, since each household's demand for good $g$ at given prices and incomes can be expressed as $m_{g} h_{g}^{*}\left(p_{1} m_{1}, p_{2} m_{2}, \ldots, p_{n} m_{n} ; I\right)$, where $I$ denotes income. This is a very special functional form, however, and although some generalizations are possible, they only permit inferences about the form of $u$ for different households to be made in exceptional cases.

Yet the main objection to these approaches is rather different. It is simply that, if we measure utility interpersonally by $u(x, y / n)$ in the Mirrlees model, we neglect the possibility that being more skilled actually confers extra utility in its own right. Any class of utility functions of the form

$$
\tilde{u}(n, x, y / n) \equiv \phi(n, u(x, y / n))
$$

with $\phi(n, \cdot)$ increasing in $u$ for each fixed $n$, produces identical utility maximizing demand and supply behaviour, but usually very different interpersonal comparisons. Similarly, in the model with household composition effects, if we measure utility interfamilially by $u\left(x_{1} / m_{1}, x_{2} / m_{2}, \ldots, x_{n} / m_{n}\right)$. Then, as Pollak and Wales (1979), Deaton and Muellbauer (1986), and Fisher (1987) have all pointed out, we neglect the possibility that a household with more children may be better off just because it has more children, even if it consumes an equivalent bundle of goods to a household with no children or fewer children. Indeed, any class of utility functions of the form

$$
\tilde{u}\left(m_{1}, m_{2}, \ldots, m_{n} ; x_{1}, x_{2}, \ldots, x_{n}\right) \equiv \psi\left(m_{1}, m_{2}, \ldots, m_{n} ; u\left(\frac{x_{1}}{m_{1}}, \frac{x_{2}}{m_{2}}, \ldots, \frac{x_{n}}{m_{n}}\right)\right),
$$

where $\psi\left(m_{1}, m_{2}, \ldots, m_{n}, \cdot\right)$ is increasing in $u$ for each fixed $m_{1}, m_{2}, \ldots, m_{n}$, generates identical utility maximizing demands for commodities, but usually very different interfamily comparisons. The postulate of isomorphy in this simple form forces us to neglect such possibilities altogether. In the more general Arrow (1977) approach, however, we can include things like skill and children as characteristics which are desirable in themselves. 
It has been suggested that simple isomorphy may be recoverable if we consider the choice of family size and of household composition within a utility maximizing framework, or the choice of skill level when this results from decisions concerning education. But even if one believes in utility maximization as strongly as does Becker (1981) when it comes to "human capital" or family composition decisions, it is far from clear that the appropriate utility function is being maximized. Family composition is chosen for reasons which are not purely self-interested - or at least one hopes this is usually the case. And the choice of how skilled one wants to be is a difficult one to make according to usual expected utility maximizing criteria, since it is virtually impossible to appreciate all the possible consequences of acquiring skills without actually acquiring them.

It seems that to make isomorphy a basis for ICUL's requires doing as Arrow (1977) suggests and including lots of extraneous variables. Then, however, we have gone beyond a purely behaviourist model because many of the extraneous variables will be inherited or exogenous rather than consequences of the individual's own behaviour. We have virtually reverted to "fundamental preferences". And, as I remarked before, such preferences are unlikely to be observable. Little is gained, it seems, by considering preferences under isomorphy instead of fundamental preferences, which they closely resemble.

\subsection{Intrapersonal Comparisons}

Recently, Gibbard $(1986,1987)$ has pursued an idea which had earlier been developed by Harsanyi (1955, and 1977a, p. 59) and Jeffrey (1971). This suggests basing the notional ICU's which ethical theory seems to require upon the intrapersonal comparisons of utility which many of us find ourselves implicitly making throughout our lives. Similar ideas are also considered by Griffin (1987), Broome (1988) and many others. After all, the argument goes, we are confronted many times with opportunities to make decisions which affect our personal characteristics, including our tastes, habits, predilections, etc. Implicitly, at least, any such decision involves comparing different potential personal characteristics. It happens that these are different characteristics for the same person, but why should 
that make any difference? Thus, this approach supplies us with the beginnings of a theory which is based on actual preferences. Two serious problems remain, however, both of which Gibbard for one readily admits. In fact Gibbard even uses these problems as arguments why one should be sceptical about the possibility of basing an individual welfare function on intrapersonal comparisons, let alone the possibility of basing a social welfare function on interpersonal comparisons.

The first difficulty, which is more obvious, is that any given individual - particularly a mature adult to whose preferences we might want to give much more weight than to those of a child - is only likely to face choices between a rather limited range of different possible personal characteristics. Somebody who does not learn in youth a particular kind of skill like mathematics, foreign languages, ability with a particular musical instrument, or in gymnastics or ball games, will find it much harder to achieve real mastery of the skill later on in life. Some personal characteristics are virtually impossible to change, such as one's genetic inheritance. Indeed, how does one completely forget one's unbringing? So the range of interpersonal comparisons of utility which can be inferred from such practical intrapersonal comparisons of utility is unfortunately rather limited. Ortuño-Ortin and Roemer (1987) have an interesting suggestion for piecing together local intrapersonal comparisons into a global intrapersonal welfare function, but it depends on assumptions which may limit its applicability too severely.

The second difficulty with this theory relates to the general issue of whether it is right to infer how to make ethical decisions from individual's actual preferences. In economics the "consumer sovereignty" value judgement states that the goods and services which an individual wants to buy enhance that individual's welfare and so are ethically desirable. As Lerner (1972) put it:

As a social critic, I may try to change some desires to others of which I approve more, but as an economist I must be concerned with the mechanisms for getting people what they want, no matter how these wants are acquired.

$$
\text { - LERNER (1972, p. 258). }
$$

Many economists accept this value judgement so unquestioningly that they even forget that it is a value judgement. Yet, when it comes to individuals who 
reveal a preference for becoming addicted to certain drugs, most people - even most economists - generally reject consumer sovereignty. Such self-destructive behaviour is clearly just one extreme instance of the general possibility noticed by Harsanyi (1953a) and Pollak (1976), for instance, that people do not always make ethically appropriate intrapersonal comparisons of utility, because they wind up acquiring inappropriate personal characteristics. So it is doubtful whether individual behaviour can be relied on to reveal fundamental preferences, partly because the relevant characteristics include tastes which themselves have to be inferred from behaviour, and partly because individuals will usually be too myopic to maximize consistently any such fundamental preferences.

Of course, Harsanyi also claimed to be using intrapersonal comparisons. His approach rests on "the postulate that the preferences and utility functions of all human individuals are governed by the same basic psychological laws," (Harsanyi, 1975b, p. 600). But, unlike the theory just enunciated, Harsanyi allows comparisons to extend to all "hypothetical conditions" in which a person has a different characteristic. Some such "hypothetical conditions" could never be met in practice; an individual cannot become a younger person, for instance, or have different natural parents. For this reason, I prefer to regard Harsanyi as postulating a fundamental utility function.

\section{Interpersonal Comparisons and Ethical Decisions}

\subsection{The Direct Approach to Social Welfare Measurement}

The attempt to base ethically relevant ICU's upon empirical observations, particularly observations of behaviour, has not surprisingly run into Hume's Law which claims that normative statements cannot rest upon purely empirical foundations. The only alternative is to recognize from the start that ethically relevant ICU's are bound to depend upon ethical value judgements, at least in part, and so will almost certainly also have to be subjective. Indeed, even intrapersonal comparisons, and the construction of an ethically relevant individual welfare function, are bound to contain similar subjective ethical value judgements. There is no 
system of ethical standards which is not largely subjective, at least when we try to come up with as precise a system as that implied by a social welfare ordering.

Once we recognize that such ICU's are bound to be subjective, and so that any derived social welfare ordering is bound to be subjective, there is much to be said for looking directly at the ordering itself. This is particularly true in economic contexts, where the issue of how to trade off total real income against inequality of real income may even suffice to determine a social welfare function - cf. Atkinson (1970), and Sen's (1978) criticism of inequality measures. This is the direct approach to social welfare measurement. It is, of course, the one which Bergson (1938) and many others have adopted, at least implicitly. Such an approach typically relies on ICU's because otherwise we would have a dictatorship (see Roberts, 1980c, and the papers cited therein, as well as Kemp and $\mathrm{Ng}, 1987$ ). But if it is easier to think what is a good social welfare ordering, rather than how to make ICU's, why should we not start with the ordering and have it reveal the ICU's, instead of starting with ICU's and trying to derive a social ordering? Especially if it is not at all clear anyway how to incorporate ICU's into a social ordering even if we believe we have made securely founded and ethically relevant interpersonal comparisons of both utility levels and utility differences. This direct approach is well exemplified by the experiments of Yaari and Bar-Hillel (1984) and of Schokkaert and Overlaet (1989). It is also advocated in the conclusion of Kaneko (1984).

\subsection{Can Interpersonal Comparisons Have Ethical Significance?}

The direct approach to distributional judgements, however, essentially only masks the key question: what ethical significance can we attach to the implicit ICU's, if any (cf. Sen, 1979)? To summarize, as pointed out by Rothenburg (1961, pp. 268-9), most existing treatments of ICU's consider only hypothetical decisions requiring that individuals imagine themselves becoming other individuals. The same is true of Arrow's (1963) discussion of "extended sympathy". As Adam Smith put it: 
How selfish soever man may be supposed, there are evidently some principles in his nature, which interest him in the fortune of others, and render their happiness necessary to him, though he derives nothing from it except the pleasure of seeing it. Of this kind is pity or compassion, which we feel for the misery of others, when we either see it, or are made to conceive it in a very lively manner...

That this is the source of our fellow feeling for the misery of others, that it is by changing places in fancy with the sufferer, that we come either to conceive or to be affected by what he feels, may be demonstrated by many observations, if it should not be thought sufficiently evident of itself.

- SмIтн (1759), pp. 1-3.

Harsanyi (1977a, fn. 4, p. 293) seeks to rebut Rothenburg's argument that ICU's depend on "changing places" in this way. Indeed, the transition from being nobody in particular in an original position, to a particular person later on, really is different. But there is a sense in which person $A$ becomes $B$ as the result of two transitions: first, back from being $A$ to the original position; second, forward from the original position to being $B$. In any case, the ethical relevance of such original position arguments remains controversial.

Indeed, the reason for not allowing ICU's which Arrow offered in Social Choice and Individual Values, as quoted at the end of Section 2, was recently repeated somewhat more forcefully:

Interpersonal comparisons of utility cannot be given decision-theoretic significance. That is, there is no decision-theoretic meaning for a statement such as, 'a movie gives me more utility than an opera gives you,' because neither of us could ever be forced to choose between being me at a movie and you at an opera.

- Myerson (1985, pp. 238-9).

The real trouble with most existing approaches to ICU's is precisely the failure to integrate them properly within a comprehansive framework based on ethically relevant decisions. People cannot change places, or be put into an original position. Information regarding utility comparisons cannot just be postulated, without explaining what decisions it explains or relates to.

Sen (1970a, b) and many succeeding articles published during the 1970's incorporate ICU's in formal social choice theory in a different way. But that work mostly treated ICU's as additional information which merely places restrictions on the invariance class of transformations to individuals' utility functions that are 
required to leave the social decision norm unchanged. No practical procedure for making such ICU's were suggested. In Sen's approach, ICU's were not directly related to any ethical decisions which could possibly arise in practice.

The time has come to see what is possible when interpersonal comparisons are explicitly related to choices of people.

\subsection{Interpersonal Comparisons Revealed by Choice of People}

There are certainly many real life decisions which do involve genuine interpersonal comparisons, if not always interpersonal comparisons of utility. We choose people as spouses, friends, colleagues, employees, employers, landlords, tenants, doctors, lawyers, investment advisers, members of our sports teams or social clubs. Doctors choose people as candidates for organ transplants. Immigration officers choose people, or reject them, as do governments with the power to withhold exit visas. To a certain extent, even conference organizers and participants choose each other, as do writers and their readers. The opening two sentences of Harsanyi (1987b) recognize this:

Suppose I am left with a ticket to a Mozart concert I am unable to attend and decide to give it to one of my closest friends. Which friend should I actually give it to?

Indeed, consider the choice between person $i$ at a film and person $j$ at an opera, which Myerson claimed could not be given decision-theoretic meaning. Myerson was right that it may be hard for a film enthusiast like $i$ to imagine becoming an opera-lover like $j$, or for person $j$ to imagine becoming somebody like $i$ who prefers the cinema to the opera. And he was right that this is exactly the kind of comparison which virtually all existing work on ICU's would have us contemplate. Yet other much more meaningful comparisons by third parties are certainly possible, even between film- and opera-goers. A municipal authority, for example, may be contemplating whether to use a certain piece of land or an existing building for either a cinema or an opera house - it is then involved in rather direct interpersonal comparisons between having more people in the city who see more films, or more people who see more opera. A private profit-maximizing entertainment company, making a similar decision, will value cinema- and opera-goers by the 
profits they are expected to generate, which is even a quantitative interpersonal comparison.

At first it might seem that such choices of people have no bearing on our problem of making interpersonal comparisons of utility. One chooses friends mostly for the value of their friendship, not because of their individual utility. Yet, in a sense, friends are being chosen precisely for their utility as friends to the person choosing to befriend them. Interpersonal comparisons of this utility as friends are being revealed by the choice of one's friends, according to this view. The entertainment company, or any other profit-maximizing company, attaches a measure of "utility" to each customer equal to the profit which that customer is expected to generate. Of course, these are person. 1 preferences and personal measures of utility, which need not necessarily have any ethical significance.

\subsection{The Utilities of Persons to Society}

The ethical interpersonal comparisons of utility that are hidden in the idealized version of Harsanyi's utilitarianism are actually rather similar to those just discussed. They represent, in a sense, preferences regarding the kinds of people which it is desirable to have in the society. An ethical interpersonally comparable utility function measures an ethical observer's view of the utility of a person to the society as a whole. Moroever, the utility of a person can change along with that person's circumstances, such as income or social status. Indeed, it could happen that this measure of the utility of a person increases if and only if the person moves to situations which he himself prefers, although this is by no means necessary.

To understand this approach properly requires examining carefully the precise form which idealized or "fundamental" utilitarianism takes. As explained in Hammond (1987a, 1988c), it requires choosing among the feasible probability distributions over possible values of $\left(x, \theta^{M}, M\right)$ in order to maximize the expected value of the welfare sum

$$
W\left(x, \theta^{M}, M\right) \equiv \sum_{i \in M} v\left(x, \theta_{i}\right)
$$

Here $M$ denotes the variable set of individuals in the society, $x$ denotes the usual 
social state (or economic allocation), $\theta^{M}$ denotes the profile $\left\langle\theta_{i}\right\rangle_{i \in M}$, where $\theta_{i}$ denotes individual $i$ 's personal characteristics, which determine tastes, values, etc., and $v$ denotes the common fundamental NMUF. This is just (the expected value of) the total utility objective of classical utilitarianism, but with a very different concept of an individual's "utility."

As Yaari (1981) points out, Edgeworth (1881, p. 117) dismissed what Hutcheson called "the greatest happiness for the greatest numbers" as meaningless, like "greatest illumination with the greatest number of lamps." But Yaari's argument (p. 17) that maximization of (10) is "meaningless" is at best incomplete. Because the special form of distribution problem he considers places no natural limit on numbers of individuals, the maximand can indeed become arbitrarily large. An analogy is that the consumer's utility function in neoclassical demand theory may also be made arbitrarily large, unless it happens to be bounded above. Realistically, however, the set of feasible intertemporal population streams is bounded, for any finite time horizon. This also disposes of G. Dworkin's (1982) (apparently deliberately frivolous) rejection of utilitarianism, which is very similar to Yaari's. Anyway, one is usually choosing among a small number of different feasible policies affecting both population and resource allocation. Yaari's ingenious reformulation of classical utilitarianism therefore strikes me as being neither necessary nor convincing. Other objections to this population objective are discussed, for instance, in Dasgupta (1988), Hammond (1988c), the work cited in those papers, and also Schwartz (1979). None seems to me very persuasive when the welfare objective (10) is properly understood.

Implicit in (10) are at least three different types of ICU's, all of which have received considerable attention in the past. Now, in addition, they will be related to hypothetical ethical choices of potential persons, as befits ethical ICU's.

First, one has level comparisons of utility of the form

$$
v\left(x_{1}, \theta_{i}\right)>v\left(x_{2}, \theta_{j}\right)
$$

This typical comparison has the obvious meaning that, if it were possible to re- 
place an individual $i$ in situation $\left(x_{1}, \theta_{i}\right)$ with the same or another individual $j$ in situation $\left(x_{2}, \theta_{j}\right)$, then that would be a desirable change, ceteris paribus.

Second, one has difference comparisons of utility of the typical form

$$
v\left(x_{1}, \theta_{i}\right)-v\left(x_{2}, \theta_{j}\right)>v\left(x_{3}, \theta_{k}\right)-v\left(x_{4}, \theta_{\ell}\right) .
$$

This can be interpreted as meaning that, if it were possible to have an increase in the probability of replacing an individual $i$ in situation $\left(x_{1}, \theta_{i}\right)$ with another individual $j$ in situation $\left(x_{2}, \theta_{j}\right)$ which is exactly equal to the decrease in the probability of replacing an individual $k$ in situation $\left(x_{3}, \theta_{k}\right)$ with another individual $\ell$ in situation $\left(x_{4}, \theta_{\ell}\right)$, then that would be a desirable change, ceteris paribus.

The third kind of comparison is of an individual's utility level with zero, and it takes one of the two alternative forms

$$
v\left(x, \theta_{i}\right)>0
$$

or

$$
v\left(x^{\prime}, \theta_{j}\right)<0 .
$$

The typical comparison (13) has the obvious meaning that, if it were possible to replace a society in which individual $i$ will never exist with another society in which individual $i$ will exist and be in situation $\left(x, \theta_{i}\right)$, then that would be a desirable change, ceteris paribus. On the other hand, the reverse typical comparison (14) has the obvious meaning that, if it were possible to replace a society in which individual $j$ will exist and be in situation $\left(x^{\prime}, \theta_{j}\right)$ with another society in which $j$ will never exist, then that would also be a desirable change, ceteris paribus.

These interpretations of the three kinds of comparison which have received most attention in the past are rather obvious, given that one accepts the desirability of the utilitarian welfare objective (10) for all kinds of policy decision, including those that affect the future numbers of individuals in the society, as well as the distribution of personal characteristics within it. 


\subsection{Utility Ratios as Marginal Rates of Substitution}

In fact, once we allow the possibility of grouping individuals into one of several categories of "ethically identical" individuals, the fundamental utility function can be given another interpretation which should be familiar to economists. For, if $N(x, \theta)$ denotes the number of individuals who have personal characteristic $\theta$ when the social state is $x$, then (10) can be written as

$$
W\left(x, \theta^{M}, M\right) \equiv \sum_{\theta} N(x, \theta) v(x, \theta) \equiv V(\mathbf{N}(x, \cdot))
$$

Here $V(\mathbf{N}(x, \cdot))$ is a linear function of the vector $\mathbf{N}$ with components $N(x, \theta)$ (all $\theta \in \Theta$ ). Then (15) says that the social ordering should have linear indifference curves in the space of possible vectors $\mathbf{N}$, with constant marginal rates of substitution $v(x, \theta) / v\left(x, \theta^{\prime}\right)$ between the numbers of individuals with any pair $\theta, \theta^{\prime}$ of personal characteristics. Such constant marginal rates of substitution determine, for each fixed $x$, an interpersonally comparable utility function $v(x, \cdot)$ on the domain of possible values of $\theta$. This function is unique up to cardinal ratio scale transformations of the form

$$
\tilde{v}(x, \theta) \equiv \alpha(x) v(x, \theta)
$$

for any $\alpha(x)>0$ which is independent of $\theta$. This implies that the entire fundamental utility function $v(x, \theta)$ can be constructed by combining:

(i) any one type of individual's von Neumann-Morgenstern utility function $v(\cdot, \bar{\theta})$ defined on all social states $x$, whose expected value represents the utility to society of a $\bar{\theta}$-person for any given lottery over such social states;

(ii) the unique marginal rates of substitution $v(x, \theta) / v(x, \bar{\theta})$ between $\theta$-persons and $\bar{\theta}$-persons in each social state $x$.

The result is a function $v(x, \theta)$ which is unique up to ratio-scale transformations of the forms

$$
\tilde{v}(x, \theta) \equiv \alpha v(x, \theta)
$$


where now $\alpha>0$ is also independent of $x$.

Take the specific case where $x=y(\cdot)$, an income distribution function $y(\theta)$ defined for all types of individual $\theta$, and where each individual's welfare becomes just $w(y(\theta))$, a function of just own income. Then equation (15) becomes

$$
V(n(\cdot))=\sum_{y} n(y) w(y)
$$

where $n(y)$ is the number of individuals who share income level $y$. Then the interpersonally comparable utility of income function $w(y)$ is simply determined from marginal rates of substitution between numbers of people with different incomes. Notice that $w(y)$ could be negative for some values of $y$. Nor is there any presumption yet that $w$ is increasing in $y$, though that is probably a restriction which one's ethics would imply - the utility to a society of richer people exceeds that of poorer.

Finally, it is tempting to explore the implications of assuming that a function like (18) represents a nation's preferences not only over income distributions but also over immigration policies. For then the ratios $w(y) / w\left(y^{\prime}\right)$ represent marginal rates of substitution between immigrants (and existing residents too, indiscriminately) of different earning capacities. If immigration policy is then insensitive to earning capacity beyond a certain threshold $\bar{y}$, that would imply that the marginal utility of income drops to zero, for $y>\bar{y}$ ! On the other hand, if immigrants with income $y$ below some lower limit $\underline{y}$ are regarded as undesirable - i.e., $w(y)<0$ for all $y<y$ - that tends to suggest that there may be exceptional benefits from raising the incomes of existing poor residents to at least $\underline{y}$. It also suggests, of course, that society would be better off if it could prevent the birth of individuals with incomes below $y$. No doubt the function (20) is far too simplistic for discussing immigration or population policy, even assuming that objectives are limited to national rather than world welfare, that only the distribution of income is ethically relevant, and that immigrants are treated on the same basis as nationals. Yet it does illustrate some of the possibilities which begin to emerge from integrating the choice of people into our welfare objectives. 
Despite the promise of such an approach, there has been a remarkable reluctance, apparently, to try to relate the ICU's which utilitarian ethical theory needs to explicit decisions of this kind. That may well be because we feel uncomfortable when confronted with such decisions, since they tend to remind us of the evils of Hitler's Mein Kampf which were put into practice, or those of Aldous Huxley's Brave New World which have not been as yet. But then any all-encompassing ethical theory of this kind is bound to embrace many different possible values, some of which may be extremely unethical. It seems to me high time that the ethical issues regarding the choice of persons should be confronted more openly and honestly.

\section{Summary of Where We Stand}

Needless to say I do not at all deny that, in the course of evolution of economics as we know it, there has been a good deal of intermixture of political and ethical discussion with the scientific discussion of fact and possibility. I shall shortly be discussing this matter further in the light of certain specific instances; and it will not appear that, provided the logical difference between the two kinds of propositions is clearly kept in mind, I am in the least hostile to the combination. In that youthful book of mine which evoked such fervid denunciation, I expressly denied that my position involved the view that 'economists should not discuss ethical or political questions any more than the position that botany is not aesthetics means that botanists should not have views on the layout of gardens.' On the contrary I went on to argue, 'it is greatly to be desired that economists should have speculated long and widely on these matters.' As you will see later on, my position today only involves a slight purely semantic modification of this pronouncement. I still hold that the distinction of the different kinds of propositions is inescapable and that we run the dangers of intellectual confusion on our own part and justifiable criticism from outside if we do not explictly recognize it.

Interpersonal comparisons of utility (ICU's) have to be made if there is to be any satisfactory escape from Arrow's impossibility theorem, with its implication that individualistic social choice has to be dictatorial (or at least oligarchic), or else that is has to restrict itself to recommending Pareto improvements. Even dictatorship, in fact, embodies interpersonal comparisons in the choice of the dictator, as do oligarchies in their choice of the oligarchs.

ICU's can be comparisons of utility levels or of utility differences, but even after they have been made, traditional theory does not really tell us how they should 
be incorporated into a social welfare functional (cf. Roberts, 1980a, b; Blackorby, Donaldson and Weymark, 1984; and d'Aspremont, 1985). Nor have existing attempts to derive ICU's from imaginary decisions behind a veil of ignorance, or from preferences about the type of person one might wish to become, or from individual behaviour, yet yielded anything sufficiently definite and specific to apply to a broad class of ethical decision problems. It is true that, for some purposes, one could circumvent the problem just by specifying what seems an ethically attractive Bergson social welfare function, based on a fundamental form of Harsanyi's utilitarianism, and letting ICU's emerge from the analysis. Yet this would seem to be unnecessarily evasive.

These considerations then suggest the need to consider the relationship between ICU's and explicit ethical choices regarding numbers of different types of people in the population. The result is an enriched social choice theory, capable of handling a broader range of ethical decision problems, in which the ICU's are explicit and play a clear role in the analysis. Utility becomes determined up to a cardinal ratio scale, with zero signifying the level at which society is indifferent between creating that type of person as a new member and not. Utility ratios are marginal rates of substitution between numbers of differents types of people.

The primary content of all such ICU's, however, is entirely ethical. Indeed, even the primary content of the utility or individual welfare functions which are being compared interpersonally must be entirely ethical, since such functions represent the relative ethical desirability of different decisions which affect only one individual. Empirical evidence can be of great relevance, but judgements of what sort of empirical evidence bears on the question of how to construct a fully comparable fundamental utility function, as required by the kind of extension of Harsanyi's theory which I am contemplating, are inevitably ethical value judgements. Hume's Law refuses to release its iron grip. The empirical content of the fundamental interpersonally comparable utility function is precisely the empirical content of the utilitarian ethical theory based on maximizing the expected sum of this utility function over all individuals and all potential individuals - no more, and no less. 
In a sense, we have gone back to the "fundamental preferences" considered in Section 4 above. The difference is that these preferences need not be derived from individuals' "impersonal preferences" in some kind of original position, behind a veil of ignorance. Instead they are based on the values of the ethical observer, as influenced by that observer's understanding of the individual's psychology and the observer's view of how society benefits from creating that individual or changing the individual's situation. As Scanlon (1987) suggests, we need to construct a more concrete conception of welfare in terms of particular goods and conditions generally recognized as important to a good life even by people with divergent values.

Similar ideas receive extensive discussion in Sen (1980, 1984, 1985, 1987b), Griffin $(1986,1987)$, etc.

To repeat, ethical ICU's really do require that an individual's utility be the ethical utility or worth of that individual to the society.

\section{ACKNOWLEDGEMENTS}

This paper is an extensive revision of one presented at the Sloan Conference on "Interpersonal Comparability of Welfare" at the University of California at Davis, April 17-18, 1987. That paper was itself was based on a much earlier paper prepared in connection with the workshop on "Interpersonal Comparisons of Utility" (organized jointly with Menahem Yaari) at the Institute for Mathematical Studies in the Social Sciences, Stanford University, on August 20th, 1981. Research support from the National Science Foundation under Grant No. SES 79-24831 for preparing that workshop, and later from the Guggenheim Foundation, is gratefully acknowledged. I am particularly indebted to Kenneth Arrow, Frank Hahn, James Mirrlees, Amartya Sen and Menahem Yaari for fruitful discussion in connection with the earlier paper, and to Charles Blackorby, Daniel Hausman, Christian Seidl, and John Weymark for helpful comments on various revisions. 


\section{Bibliography}

In addition to all the items referred to in the preceding paper, several other works discussing interpersonal comparisons have been added, but the resulting list is almost certainly incomplete - possibly seriously so. Articles in collected volumes or reprinted therein may not be listed individually unless they are referred to in the paper. D'Aspremont (1985) and Sen (1986) also contain extensive references.

For bibliographic research assistance, especially in using the DIALOG and Philosopher's Index databases, my thanks to Jeffrey Coles, who was my research assistant in 1981, and also to Peter Kennealy and Milica Uvalic of the European University Institute Library.

P.W. Abelson (1987), "Fairness in the Real World: Rules, Choices, Expectations, and Policies," Australian Economic Papers, 26: 1-19.

T. Amemiya (1981), "Qualitative Response Models: A Survey," Journal of Economic Literature, 19: 1483-1536.

G.C. Archibald $(1959,1965)$, "Welfare Economics, Ethics and Essentialism," and "A Reply," Economica, 26: 316-27, and 32: 226-7.

W.E. Armstrong (1951), "Utility and the Theory of Welfare," Oxford Economic Papers, 3: 259-271.

K.J. Arrow (1951, 1963), Social Choice and Individual Values (2nd edn.). New Haven: Yale University Press.

K.J. Arrow (1972), "Exposition of the Theory of Choice under Uncertainty," in Decision and Organization edited by C.B. McGuire and R. Radner (Amsterdam: North-Holland), ch. 2, pp. 19-55; reprinted in Arrow (1984).

K.J. Arrow (1973), "Some Ordinalist-Utilitarian Notes on Rawls's Theory of Justice," Journal of Philosophy, 70: 245-263; reprinted in Arrow (1983).

K.J. Arrow (1977), "Extended Sympathy and the Possibility of Social Choice," American Economic Review (Papers and Proceedings), 67: 219-25; reprinted in Arrow (1983).

K.J. Arrow (1983), Collected Papers of Kenneth J. Arrow, Vol. 1: Social Choice and Justice. Cambridge, Mass.: Harvard University Press. 
K.J. Arrow (1984), Collected Papers of Kenneth J. Arrow, Vol. 3: Individual Choice under Certainty and Uncertainty. Cambridge, Mass.: Harvard University Press.

K.J. Arrow (1987), "Reflections on the Essays," in Feiwel (1987), ch. 35, pp. $727-734$.

C. D'Aspremont (1985), "Axioms for Social Welfare Orderings," in Hurwicz, Schmeidler and Sonnenschein, ch. 2, pp. 19-76.

C. D'Aspremont (1988), "Utility Comparisons and Bayesian Revelation Mechanisms," presented to the Sloan conference on "Interpersonal Comparability of Welfare," University of Chicago.

C. D'Aspremont And L. Gevers (1977), "Equity and the Informational Basis of Collective Choice," Review of Economic Studies, 44: 199-209.

A.B. AtKinson (1970), "On the Measurement of Inequality," Journal of Economic Theory, 2: 244-63.

R.J. Aumann (1985), "Value, Symmetry, and Equal Treatment: A Comment on the Roth-Shafer Examples," Econometrica, 53: 667-677.

R.J. Aumann (1986), "Rejoinder," Econometrica, 54: 985-989.

R.J. Aumann (1987), "On the Non-transferable Utility Value: A Comment on Scafuri and Yannelis," Econometrica, 55: 1461-1464.

R.J. Aumann and M. Kurz (1977), "Power and Taxes," Econometrica, 45: 1137-1161.

A.J. AYER (1936, 1971), Language, Truth and Logic. Harmondsworth: Penguin Books. 
E. BARONE (1908), "Il ministero della produzione nello stato colletivista," Giornale degli Economisti, 37: 267-293, 391-414; translated as "The Ministry of Production in the Collectivist State" in F.A. Hayek (ed.) (1935), Collectivist Economic Planning (London: Routledge \& Kegan Paul), pp. 310-334, and reprinted in P. Newman (ed.), Readings in Mathematical Economics, Vol. I: Value Theory (Baltimore: The Johns Hopkins Press).

A.P. Barten (1964), "Family Composition, Price, and Expenditure Patterns," in Econometric Analysis for National Economic Planning (16th Symposium of the Colston Society) edited by P. Hart, G. Mills, and J.K. Whitaker (London: Butterworth), pp. 277-292.

B. BARRY (1973), The Liberal Theory of Justice. Oxford: Clarendon Press.

G. BECKER (1974), "Difficulties with Bare Preferences," Theory and Decision, 5: 329-331.

G.M. Becker, M.H. DeGroot and J. MarschaK (1963), "Stochastic Models of Choice Behavior," Behavioral Science, 8: 41-55.

G.S. BeCKer (1981), A Treatise on the Family. Cambridge, Mass.: Harvard University Press.

A. Bergson (1938), "A Reformulation of Certain Aspects of Welfare Economics," Quarterly Journal of Economics, 52: 310-334.

A. Bergson (1983), "Pareto on Social Welfare," Journal of Economic Literature, 21: $40-46$.

L. Bergstrom (1982), "Interpersonal Utility Comparisons," Grazer Philosophical Studies, 16/17: 283-312.

T. BEZEMBINDER AND P. VAN ACKER (1987), "Factual versus Representational Utilities and Their Interdimensional Comparisons," Social Choice and Welfare, 4: 79-104. 
C. Blackorby and D. Donaldson (1982), "Ratio-scale and Translation-scale Full Interpersonal Comparability without Domain Restrictions: Admissible Social Evaluation Functions," International Economic Review, 23: 249-268.

C. Blackorby and D. Donaldson (1987), "Adult-Equivalence Scales and the Economic Implementation of Interpersonal Comparisons of Well-Being," presented to the Sloan Conference on "Interpersonal Comparability of Welfare" at the University of California, Davis.

C. Blackorby, D. Donaldson and J. Weymark (1984), "Social Choice with Interpersonal Utility Comparisons: A Diagrammatic Introduction," International Economic Review, 25: 327-356.

R.W. Boadway and N. Bruce (1984), Welfare Economics. Oxford: Basil Blackwell.

P.J.M. VAN Der Bogard and J. Versluis (1960), "The Design of Socially Optimal Decisions," in Proceedings of the Second International Conference on Operations Research (New York: John Wiley).

L. Bovens (1987), "On Arguments from Self-Interest for the Nash Solution and the Kalai Egalitarian Solution to the Bargaining Problem," Theory and Decision, 23: 231-260.

R.B. Brandt (1979), A Theory of the Good and the Right. Oxford: Clarendon Press.

D. Braybrooke (1982), "The Maximum Claims of Gauthier's Bargainers: Are the Fixed Social Inequalities Acceptable?," Dialogue (Canada), 21: 411-429.

K. Breault (1981), "Modern Psychophysical Measurement of Marginal Utility; A Return to Introspective Cardinality?," Social Science Quarterly, 62: 672-684.

D.W. Brock (1973), "Recent Work in Utilitarianism," American Philosophical Quarterly, 10: 241-276. 
H.W. Brock (1978a), "A Critical Discussion of the Work of John C. Harsanyi," Theory and Decision, 9: 349-367.

H.W. Brock (1978b), "A New Theory of Social Justice Based on the Mathematical Theory of Games," in Game Theory and Political Science edited by P.C. Ordeshook (New York: New York University Press), pp. 563-627.

H.W. Brock (1979a), "A Game Theoretic Account of Social Justice," Theory and Decision, 11: 239-265; reprinted in Brock (1979b).

H.W. Brock (ED.) (1979b), Game Theory, Social Choice and Ethics. Dordrecht: D. Reidel.

H.W. Brock (1980), "The Problem of 'Utility Weights' in Group Preference Aggregation," Operations Research, 28: 176-187.

J. Broомe (1988), "Utilitarian Metaphysics?," presented to the Sloan Conference on "Interpersonal Comparability of Welfare" at the University of Chicago.

S.T. BUCCOLA (1988), "Social Welfare and Interpersonal Utility Comparisons in Applied Policy Research," American Journal of Agricultural Economics, 70: $454-58$.

A. Самасно (1986), "Individual Cardinal Utility, Interpersonal Comparisons, and Social Choice," in Recent Developments in the Foundations of Utility and Risk Theory edited by L. Daboni, A. Montesano, and M. Lines (Dordrecht: D. Reidel), pp. 185-200.

A. Camacho and J. Sonstelie (1974), "Cardinal Welfare, Individualistic Ethics, and Interpersonal Comparisons of Utility: A Note," Journal of Political Economy, 82: 607-611.

J.S. Chipman (1987), "Compensation Principle," in Eatwell, Milgate and Newman.

J.S. Chipman and J.C. Moore (1978), "The New Welfare Economics, 1939-1974," International Economic Review, 19: 547-584. 
G.A. Cohen (1989), "On the Currency of Egalitarian Justice," Ethics, 99: 906-944.

R.D. COOTER AND P. RAPPOPORT (1984), "Were the Ordinalists Wrong about Welfare Economics?," Journal of Economic Literature, 22: 507-530.

R.D. Cooter And P. Rappoport (1985), "Reply to I.M.D. Little's Comment," Journal of Economic Literature, 23: 1189-1191.

R.A. Dahl (1950), A Preface to Democratic Theory. Chicago: University of Chicago Press.

P.S. Dasgupta (1974), "On Some Problems Arising from Professor Rawls' Conception of Distributive Justice," Theory and Decision, 4: 325-344.

P.S. DAsqupta (1988), "Lives and Well-Being," Social Choice and Welfare, 5: 103-126; reprinted in Gaertner and Pattanaik.

D. DAVIDSON (1986), "Judging Interpersonal Interests," in Elster and Hylland, ch. 7 , pp. 195-211.

A.S. Deaton and J. Muellbauer (1986), "On Measuring Child Costs: With Applications to Poor Countries," Journal of Political Economy, 94: 720-744.

R. Deschamps and L. Gevers (1977), "Separability, Risk-Bearing and Social Welfare Judgements," European Economic Review, 10: 77-94.

R. Deschamps and L. Gevers (1978), "Leximin and Utilitarian Rules: A Joint Characterization," Journal of Economic Theory, 17: 143-163.

P.A. Diamond (1967), "Cardinal Welfare, Individualistic Ethics, and Interpersonal Comparisons of Utility: Comment," Journal of Political Economy, 75: $765-766$.

M. Dовв (1969), Welfare Economics and the Economics of Socialism: Towards a Commonsense Critique. Cambridge: Cambridge University Press. 
G. Dworkin (1982), "A Journal of Mathematical Ethics: A Proposal," Philosophical Forum, 13: 413-415.

R. Dworkin (1981), "What Is Equality, I: Equality of Welfare," and “-, II: Equality of Resources," Philosophy and Public Affairs, 10: 185-246 and $283-345$.

J. Eatwell, M. Milgate and P. Newman (eds.) (1987), The New Palgrave Dictionary of Economics. London: Macmillan.

F.Y. Edgeworth (1881), Mathematical Psychics. London: Kegan Paul.

W. Edwards AND A. TVersky (EDS.) (1967), Decision Making. Harmondsworth: Penguin Books.

J. Elster (1986), "The Market and the Forum: Three Varieties of Political Theory," in Elster and Hylland, ch. 4, pp. 103-132.

J. Elster and A. Hylland (EDS.) (1986), Foundations of Social Choice Theory. Cambridge: Cambridge University Press, and Oslo: Universitetsforlaget.

G.R. FEIWEL (ED.) (1985), Issues in Contemporary Microeconomics and Welfare. London: Macmillan.

G.R. FeIwel (ED.) (1987), Arrow and the Foundations of the Theory of Economic Policy. London: Macmillan.

B. Fine (1975), “A Note on 'Interpersonal Aggregation and Partial Comparability'," Econometrica, 43: 169-172.

B. Fine (1985), "A Note on the Measurement of Inequality and Interpersonal Comparability," Social Choice and Welfare, 1: 273-277.

F.M. Fisher (1956), "Income Distribution, Value Judgements and Welfare," Quarterly Journal of Economics, 70: 380-424.

F.M. Fisher (1987), "Household Equivalence Scales and Interpersonal Comparisons," Review of Economic Studies, 54: 519-24. 
F.M. Fisher And J. Rothenberg (1961), "How Income Ought to Be Distributed: Paradox Lost," Journal of Political Economy, 69, : 162-180.

I. Fisher $(1892,1925)$, Mathematical Investigations in the Theory of Value and Prices, in the Transactions of the Connecticut Academy of Sciences; reprinted. New Haven: Yale University Press.

M. Fleming (1957), "Cardinal Welfare and Individualistic Ethics: A Comment," Journal of Political Economy, 65: 355-357.

M. Friedman and L.J. Savage (1948), "The Utility Analysis of Choices Involving Risk," Journal of Political Economy, 56: 279-304.

M. Friedman and L.J. Savage (1952), "The Expected Utility Hypothesis and Measurement of Utility," Journal of Political Economy, 60: 463-474.

W. Gaertner and P.K. Pattanaik (eds.) (1988), Distributive Justice and Inequality. Berlin: Springer Verlag.

P. GÄRDENFors (1978), "Fairness without Interpersonal Comparisons," Theoria, 44: 57-74.

L. Gevers (1979), "On Interpersonal Comparability and Social Welfare Orderings," Econometrica, 47: 75-90.

A.F. GibBard (1978), "Preference Strength and Two Kinds of Ordinalism," Philosophia (Israel), 7: 255-264.

A. GibBard (1986), "Interpersonal Comparisons: Preference, Good, and the Intrinsic Reward of a Life," in Elster and Hylland, ch. 6, pp. 165-193.

A. Gibbard (1987), "Ordinal Utilitarianism," in Feiwel (1987), ch. 2, pp. 135-153.

D. Goldstick (1971), "Assessing Utilities," Mind, 80: 531-541.

R.E. Goodin (1975), "How to Determine Who Should Get What," Ethics, 85: 310-321. 
L.A. Goodman and H. Markovitz (1952), "Social Welfare Functions Based on Individual Rankings," American Journal of Sociology, 58: 257-62.

S. Gordon (1973), "John Rawls' Difference Principle, Utilitarianism, and the Optimum Degree of Inequality," Journal of Philosophy, 70: 275-280.

W.M. Gorman (1956, 1980), "A Possible Procedure for Analysing Quality Differentials in the Egg Market," Review of Economic Studies, 47: 843-56.

J. Griffin (1981), "Interpersonal Comparisons of Utility (in Polish)," Etyka, 19: $45-68$.

J. GRIfFin (1986), Well-Being: Its Meaning, Measurement, and Moral Importance. Oxford: Clarendon Press.

J. Griffin (1987), "Well-Being and its Interpersonal Comparability," presented to the Sloan Conference on "Interpersonal Comparability of Welfare" at the University of California, Davis.

A.J.M. HagenaArs (1986), The Perception of Poverty. Amsterdam: North-Holland.

F.H. Hahn AND M. Hollis (EDS.) (1979), Philosophy and Economic Theory. Oxford: Oxford University Press.

A. Hallam (1988), "Measuring Economic Welfare: Is Theory a Cookbook for Empirical Analysis," American Journal of Agricultural Economics, 70: 443-447.

P.J. Hammond (1976a), "Equity; Arrow's Conditions, and Rawls' Difference Principle," Econometrica, 44: 793-804; partly reprinted in Hahn and Hollis (1979).

P.J. HAMmOND (1976b), "Why Ethical Measures of Inequality Need Interpersonal Comparisons," Theory and Decision, 7: 263-274. 
P.J. HAMmond (1977, 1980), "Dual Interpersonal Comparisons of Utility and the Welfare Economics of Income Distribution"; and "-: A Corrigendum," Journal of Public Economics, 7: 51-71 and 14: 105-106.

P.J. HАммоND (1979a), "Straightforward Individual Incentive Compatibility in Large Economies," Review of Economic Studies, 46: 263-282.

P.J. Hammond (1979b), "Equity in Two Person Situations: Some Consequences," Econometrica, 47: 1127-35.

P.J. Hammond (1982a), "The Economics of Justice and the Criterion of Wealth Maximization," Yale Law Journal, 91: 1493-1507.

P.J. Hammond (1982b), "Utilitarianism, Uncertainty and Information," in Sen and Williams, ch. 4, pp. 85-102.

P.J. Hammond (1983), "Ex-Post Optimality as a Dynamically Consistent Objective for Collective Choice under Uncertainty," in Social Choice and Welfare edited by P.K. Pattanaik and M. Salles (Amsterdam: North Holland), ch. 10 , pp. 175-205.

P.J. Hammond (1985), "Welfare Economics," in G.R. Feiwel (1985), ch. 13, pp. 405-434.

P.J. Hammond (1986), "Consequentialist Social Norms for Public Decisions," in Social Choice and Public Decision Making: Essays in Honor of Kenneth J. Arrow, Vol. 1 edited by W.P. Heller, R.M. Starr and D.A. Starrett (Cambridge: Cambridge University Press), ch. 1, pp. 3-27.

P.J. Hammond (1987a), "On Reconciling Arrow's Theory of Social Choice with Harsanyi's Fundamental Utilitarianism," in Feiwel (1987), ch. 4, pp. 179-222.

P.J. Hammond (1987b), "Markets as Constraints: Multilateral Incentive Compatibility in Continuum Economies," Review of Economic Studies, 54: 399-412. 
P.J. Hammond (1987c), "Social Choice: The Science of the Impossible?," in Feiwel (1987), ch. 1B, pp. 116-131.

P.J. Hammond (1988a), "Consequentialism and the Independence Axiom," in Risk, Decision and Rationality edited by B.R. Munier (Dordrecht: D. Reidel), pp. 503-516.

P.J. HAMmOND (1988b), "Consequentialist Foundations for Expected Utility," Theory and Decision, 25: 25-78.

P.J. Hammond (1988c), "Consequentialist Demographic Norms and Parenting Rights," Social Choice and Welfare, 5: 127-145; reprinted in Gaertner and Pattanaik.

P.J. HAMmond (1989), "Independence of Irrelevant Interpersonal Comparisons," presented to the Deutsche Forschungsgemeinschaft conference on Distributive Justice, Bonn-Bad Godesberg.

A.C. Harberger (1971), "Three Basic Postulates for Applied Welfare Analysis," Journal of Economic Literature, 9: 785-797.

R.M. HARE (1951), The Language of Morals. Oxford: Clarendon Press.

R.M. Hare (1963), Freedom and Reason. Oxford: Clarendon Press.

R.M. HARE (1981), Moral Thinking: Its Levels, Method and Point. Oxford: Clarendon Press.

R.F. HARrod (1938), "Scope and Method of Economics," Economic Journal, 48: 383-412.

J.C. HaRsanYi (1953a), "Welfare Economics of Variable Tastes," Review of Economic Studies, 21: 204-13.

J.C. HarsanYi (1953b), "Cardinal Utility in Welfare Economics and in the Theory of Risk-Taking," Journal of Political Economy, 61: 434-5; reprinted in Harsanyi (1976). 
J.C. HARSANYi (1955), "Cardinal Welfare, Individualistic Ethics, and Interpersonal Comparisons of Utility," Journal of Political Economy, 63: 309-321; reprinted in Phelps (1973) and Harsanyi (1976).

J.C. HARSANYI (1975a), "Nonlinear Social Welfare Functions: Do Welfare Economists Have a Special Exemption from Bayesian Rationality?," Theory and Decision, 6: 311-32; reprinted in Harsanyi (1976).

J.C. Harsanyi (1975b), "Can the Maximin Principle Serve as a Basis for Morality? A Critique of John Rawls's Theory," American Political Science Review, 69: 594-606; reprinted in Harsanyi (1976).

J.C. HarsanyI (1976), Essays on Ethics, Social Behavior, and Scientific Explanation. Dordrecht: D. Reidel.

J.C. Harsanyi (1977a), Rational Behavior and Bargaining Equilibrium in Games and Social Situations. Cambridge: Cambridge University Press.

J.C. HARSANYi (1977b), "Morality and the Theory of Rational Behavior," Social Research, 44: 623-56.

J.C. Harsanyi (1978), "Bayesian Decision Theory and Utilitarian Ethics," American Economic Review (Papers and Proceedings), 68: 223-8.

J.C. Harsanyi (1979), "Bayesian Decision Theory, Rule Utilitarianism, and Arrow's Impossibility Theorem," Theory and Decision, 11: 289-317; reprinted in Brock (1979b).

J.C. HaRsanYi (1987a), "Von Neumann-Morgenstern Utilities, Risk Taking, and Welfare," in Arrow and the Ascent of Modern Economic Theory edited by G.R. Feiwel (London: Macmillan; and New York: New York University Press), ch. 17, pp. 545-558.

J.C. Harsanyi (1987b), "Interpersonal Utility Comparison," in Eatwell, Milgate and Newman. 
D.M. Hausman (ED.) (1984), The Philosophy of Economics: An Anthology. Cambridge: Cambridge University Press:

P. Hennipman (1987), “A Tale of Two Schools: Comments on a New View of the Ordinalist Revolution," De Economist, 135: 141-162.

P. Hennipman (1988), "A New Look at the Ordinalist Revolution: Comments on Cooter and Rappoport," Journal of Economic Literature, 26: 80-91.

I.N. Herstein and J. Milnor (1953), "An Axiomatic Approach to Measurable Utility," Econometrica, 21: 291-297.

F. van Herwaarden, A. Kapteyn and B.M.S. van Praag (1977), "Twelve Thousand Individual Welfare Functions," European Economic Review, 9: 283-300.

C. Hildreth (1953), "Alternative Conditions for Social Orderings," Econometrica, 21: 81-94.

A. Hirayama (1983), "Interpersonal Comparison and Criteria of Justice," Economic Studies Quarterly, 34: 156-70.

D. Hume (1739-40, 1969), A Treatise of Human Nature. Harmondsworth: Penguin Books edition.

L. Hurwicz, D. Schmeidler And H. Sonnenschein (eds.) (1985), Social Goals and Social Organization. Cambridge: Cambridge University Press.

M. Intriligator (1973), "A Probabilistic Model of Social Choice," Review of Economic Studies, 40: 553-60.

J.R. Isbell (1959), "Absolute Games," in Conditions to the Theory of Games, Vol. IV edited by A.W. Tucker and R.D. Luce (Princeton: Princeton University Press), pp. 357-396.

J.Y. JAFFraY (1985), "Interpersonal Level Comparability Does Not Imply Comparability of Utility Differences - A Comment on $\mathrm{Ng}$," Theory and Decision, 19: 201-203. 
R.C. Jeffrey (1971), "On Interpersonal Utility Theory," Journal of Philosophy, 68: $647-56$.

R.C. JefFrey (1974), "Remarks on Interpersonal Utility Theory," in Logical Theory and Semantic Analysis edited by S. Stenlund (Dordrecht: D. Reidel), pp. 35-44.

W.S. Jevons $(1871,1970)$, The Theory of Political Economy. London: Macmillan; Harmondsworth: Penguin Books.

R.E. Just (1988), "Making Economic Welfare Analysis Useful in the Policy Process: Implications of the Public Choice Literature," American Journal of Agricultural Economics, 70: 448-453.

E. KalaI (1977), "Proportional Solutions to Bargaining Situations: Interpersonal Utility Problems," Econometrica, 45: 1623-1630.

E. Kalai and D. Samet (1985), "Monotonic Solutions to General Cooperative Games," Econometrica, 53: 307-27.

M. Kaneko (1984), "On Interpersonal Utility Comparisons," Social Choice and Welfare, 1: 165-175.

P. Kantor and R.J. Nelson (1979), "Social Decision Making in the Presence of Complex Goals, Ethics and the Environment," Theory and Decision, 10: 181-200.

A. Kapteyn (1977), A Theory of Preference Formation. 's-Gravenhage: Drukkerij J.H. Pasmans.

A. Kapteyn and B.M.S. van PraAg (1976), "A New Approach to the Construction of Family Equivalence Scales," European Economic Review, 7: 313-35.

R.L. Keeney and C.W. Kirkwood (1975), "Group Decision Making Using Cardinal Social Welfare Functions," Management Science, 22: 430-437. 
R.L. KEeney AND H. RAIFFA (1976), Decisions with Multiple Objectives: Preferences and Value Trade-Offs. New York: John Wiley.

J.S. Kelly (1978), Arrow Impossibility Theorems. New York: Academic Press.

M.C. Kemp And Y.-K. NG (1987), "Arrow's Independence Condition and the Bergson-Samuelson Tradition," in Feiwel (1987), ch. 5, pp. 223-241.

L. KeRN (1980), "Zur Axiomatischen Charakterisierung alternativer Vertragsprinzipen, [On the axiomatic characterization of alternative contract principles]," Erkenntnis, 15: 1-31.

C.P. Kindleberger (1965), Economic Development (2nd edn). New York: McGraw-Hill.

K. Klappholz (1964), "Value Judgements and Economics," British Journal for the Philosophy of Science, 15: 97-114; reprinted in Hausman (1984).

S.-C. Kolm (1972), Justice et Equité. Paris: Editions du Centre National de la Recherche Scientifique.

S.-C. Kolm (1974), "Sur les conséquences économiques des principes de justice et de justice pratique," Revue d'Economie Politique, 84: 80-107.

K.J. Lancaster (1966), "A New Approach to Consumer Theory," Journal of Political Economy, 74: 132-57.

A.P. Lerner (1944), The Economics of Control. London: Macmillan.

A.P. Lerner (1972), "The Economics and Politics of Consumer Sovereignty," American Economic Review (Papers and Proceedings), 62: 258-263.

S. Levy And L. Guttman (1975), "On the Multivariate Structure of Well-Being," Social Indicators Research, 2: 361-388.

I.M.D. LitTle (1957), A Critique of Welfare Economics (2nd edn.). Oxford: Oxford University Press. 
I.M.D. LiTtLe (1985), "Robert Cooter and Peter Rappoport, 'Were the Ordinalists Wrong about Welfare Economics?': A Comment," Journal of Economic Literature, 23: 1186-1188.

R.D. Luce (1956), "Semi-Orders and a Theory of Utility Discrimination," Econometrica, 24: 178-91.

R.D. LuCE (1959), Individual Choice Behavior. New York: John Wiley.

R.D. LUCE AND H. RAIFFA (1957), Games and Decisions: Introduction and Critical Survey. New York: John Wiley.

D. LyONS (1972), "Rawls versus Utilitarianism," Journal of Philosophy, 69: $535-545$.

A.F. MACKAY (1975), "Interpersonal Comparisons," Journal of Philosophy, 72: $535-549$.

A.F. MacKay (1980), Arrow's Theorem: The Paradox of Social Choice. New Haven: Yale University Press.

A.F. MaCKaY (1986), "Extended Sympathy and Interpersonal Utility Comparisons," Journal of Philosophy, 83: 305-322.

B. Magee (1971), Modern British Philosophy. London: Secker and Warburg.

E. MAskin (1978), "A Theorem on Utilitarianism," Review of Economic Studies, 45: 93-96.

E. MASKIN (1979), "Decision-making under Ignorance with Implications for Social Choice," Theory and Decision, 11: 319-337; reprinted in Brock (1979b).

A.C. McKennell (1978), "Cognition and Affect in Perceptions of Well-Being," Social Indicators Research, 5: 389-426.

G. MCKenzIE (1988), "Applied Welfare Economics and Frisch's Conjecture," in Welfare and Efficiency in Public Economics edited by D. Bös, M. Rose and C. Seidl (Berlin: Springer-Verlag), pp. 1-20. 
K. Menger (1934), "Das Unsicherheitsmoment in der Wertlehre, Betrachtungen im Anschluss an das sogenannte Petersburger Spiel [Expectation in value theory; considerations in connection with the so-called St. Petersburg paradox]," Zeitschrift für Nationalökonomie, 5: 459-485.

J.A. Mirrlees (1982), "On the Economic Uses of Utilitarianism," in Sen and Williams, ch. 3 , pp. 63-84.

R. MÖLLER (1983), Interpersonelle Nutzenvergleiche: Wissenschaftliche Möglichkeit und politische Bedeutung [Interpersonal comparisons of utility: scientific possibility and political meaning]. Göttingen: Vandenhoeck and Ruprecht.

J. Muellbauer (1974a), "Prices and Inequality: The United Kingdom Experience," Economic Journal, 84: 32-55.

J. Muellbauer (1974b), "Household Composition, Engel Curves and Welfare Comparison between Households: A Duality Approach," European Economic Review, 5: 103-22.

J. Muellbauer (1974c), "Inequality Measures, Prices and Household Composition," Review of Economic Studies, 41: 493-504.

J. Muellbauer (1975), "Identification and Consumer Unit Scales," Econometrica, 43: 807-???.

J. Muellbauer (1977), "Testing the Barten Model of Household Composition Effects and the Cost of Children," Economic Journal, 87: 460-87.

J. Muellbauer (1987), "Professor Sen on the Standard of Living," in Sen (1987), pp. $39-58$.

D.C. Mueller, R.D. Tollison and T.D. Willett (1974), "The Utilitarian Contract: A Generalization of Rawls' Theory of Justice," Theory and Decision, 4: 345-367.

R.B. Myerson (1977), "Two-Person Bargaining Problems and Comparable Utility," Econometrica, 45: 1623-1630. 
R.B. Myerson (1981), "Utilitarianism, Egalitarianism, and the Timing Effect in Social Choice Problems," Econometrica, 49: 883-897.

R.B. Myerson (1985), "Bayesian Equilibrium and Incentive Compatibility: An Introduction," in Hurwicz, Schmeidler, and Sonnenschein, ch. 8, pp. 229-259.

L. Narens and R.D. Luce (1983), "How We May Have Been Misled into Believing Interpersonal Comparisons of Utility," Theory and Decision, 15: 247-260.

L.T. NeILSEN (1983), "Ordinal Interpersonal Comparisons in Bargaining," Econometrica, 51: 219-21.

Y.-K. NG (1972), "Value Judgements and Economists' Role in Policy Recommendation," Economic Journal, 82: 1014-1018.

Y.-K. NG (1975), "Bentham or Bergson? Finite Sensibility, Utility Functions and Social Welfare Functions," Review of Economic Studies, 42: 545-69.

Y.-K. NG (1982), "Beyond Pareto Optimality: The Necessity of Interpersonal Cardinal Utilities in Distributional Judgements and Social Choice," Zeitschrift für Nationalökonomie, 42: 207-233.

Y.-K. NG (1984a), "Interpersonal Level Comparability Implies Comparability of Utility Differences," Theory and Decision, 17: 141-147.

Y.-K. NG (1984b), "Expected Subjective Utility: Is the Neumann-Morgenstern Utility the Same as the Neoclassical's?," Social Choice and Welfare, 1: 177-186.

Y.-K. NG (1985a), "Some Fundamental Issues in Social Welfare," in Feiwel (1985), ch. 14, pp. 435-469.

Y.-K. NG (1985b), "The Utilitarian Criterion, Finite Sensibility, and the Weak Majority Reference Principle: A Response," Social Choice and Welfare, 2: 37-38. 
Y.-K. NG (1989), "Interpersonal Level Comparability Implies Comparability of Utility Differences: A Reply," Theory and Decision, 26: 91-93.

R. NozICK (1985), "Interpersonal Utility Theory," Social Choice and Welfare, 2: 161-179.

I. Ortuño-Ortin and J.E. Roemer (1987), "Deducing Interpersonal Comparability from Local Expertise," presented to the Sloan Conference on "Interpersonal Comparability of Welfare," University of California at Davis.

V. PARETo (1894), "Il massimo di utilità dato dalla libera concorrenza, [The utility maximum given by free competition]," Giornale degli Economisti, 9: 48-66.

V. PARETo (1895), "Teoria matematica del commercio internazionale,". [Mathematical theory of international trade]," Giornale degli Economisti, 10: 476-498.

V. PAREto (1913), "Il massimo di utilità per una colletività in Sociologia," [The utility maximum for a collective in sociology]," Giornale degli Economisti, 46: 337-341.

P.K. Pattanaik (1968), "Risk, Impersonality, and the Social Welfare Function," Journal of Political Economy, 76: 1152-1169; reprinted in Phelps (1973).

E.A. Pazner (1979), "Equity, Nonfeasible Alternatives and Social Choice: A Reconsideration of the Concept of Social Welfare," in Aggregation and Revelation of References edited by J.-J. Laffont (Amsterdam: North-Holland), pp. 161-173.

E.S. PhelPs (ED.) (1973), Economic Justice. Harmondsworth: Penguin Books.

E.S. PhelPS (1977), "Recent Developments in Welfare Economics: Justice et Equité," in Frontiers of Quantitative Economics edited by M.D. Intriligator (Amsterdam: North-Holland), ch. 16, pp. 703-730.

R.A. Pollak (1976), "Habit Formation and Long-Run Utility Functions," Journal of Economic Theory, 13: 272-97. 
R.A. Pollak and T.J. Wales (1979), "Welfare Comparisons and Equivalence Scales," American Economic Review (Papers and Proceedings), 69: 216-21.

R.A. Posner (1981), The Economics of Justice. Cambridge, Mass.: Harvard University Press.

B.M.S. van PraAg (1968), Individual Welfare Functions and Consumer Behavior. Amsterdam: North Holland.

B.M.S. van PraAg (1971), "The Welfare Function of Income in Belgium: An Empirical Investigation," European Economic Review, 2: 337-69.

B.M.S. Van PraAg and A. Kapteyn (1973), "Further Evidence on the Individual Welfare Function of Income: An Empirical Investigation in the Netherlands," European Economic Review, 4: 33-62.

B.M.S. van PraAg and N.L. van der Sar (1988), "Household Cost Functions and Equivalence Scales," Journal of Human Resources, 23: 193-210.

D. RAE, et.al. (1981), Equalities. Cambridge, Mass.: Harvard University Press.

P. RAPpoport (1988), "Reply to Professor Hennipman," Journal of Economic Literature, 26: 86-91.

J. Rawls (1959), “Justice as Fairness," Philosophical Review, 67: 164-94.

J. Rawls (1971), A Theory of Justice. Cambridge, Mass: Harvard University Press.

N. Rescher (1967), "Notes on Preference, Utility and Cost," Synthese, 19: $332-43$.

N. Rescher (1969), Introduction to Value Theory. Englewood Cliffs: Prentice Hall.

L. Robbins (1932), An Essay on the Nature and Significance of Economic Science. London: Macmillan; partly reprinted in Hausman (1984). 
L. Robins (1938), "Interpersonal Comparisons of Utility: A Comment," Economic Journal, 48: 635-41.

L. Robbins (1981), "Economics and Political Economy," American Economic Review (Papers and Proceedings), 71: 1-10.

K.W.S. RoBerTs (1980a), "Possibility Theorems with Interpersonally Comparable Welfare Levels," Review of Economic Studies, 47: 409-420.

K.W.S. RoBerts (1980b), "Interpersonal Comparability and Social Choice Theory," Review of Economic Studies, 47: 421-439.

K.W.S. RoberTs (1980c), "Social Choice Theory: The Single-Profile and Multi-Profile Approaches," Review of Economic Studies, 47: 441-50.

J. Roemer (1985), "Equality of Resources Implies Equality of Welfare," Quarterly Journal of Economics, 101: 751-784.

G. Ross (1974), "Utilities for Distributive Justice: The Meshing Problem and a Solution to It," Theory and Decision, 4: 239-258.

A.E. Roth (1980), "Values for Games without Side Payments: Some Difficulties with Current Concepts," Econometrica, 48: 457-465.

A.E. Roтн (1986), "On the Non-transferable Utility Value: A Reply to Aumann," Econometrica, 54: 981-984.

J. Rothenburg (1961), The Measurement of Social Welfare. Englewood Cliffs, NJ: Prentice-Hall.

L.R. Rovig (1976), "On the Measurement of Extent of Preference, Interpersonal Comparisons, and Rates of Substitution," Intermountain Economic Review, 71: 83-84.

S. Roy (1984), "Considerations on Utility, Benevolence and Taxation," History of Political Economy, 16: 349-362. 
L. SACCONI (ED.) (1986), La Decisione: Razionalità collettiva e strategica nell'amministrazione e nelle organizzazioni. Milano: Franco Angeli.

A.J. Scafuri and N.C. Yannelis (1984), "Non-symmetric Cardinal Value Allocations," Econometrica, 52: 1365-68.

P.A. Samuelson (1937), "A Note on Measurement of Utility," Review of Economic Studies, 4: 155-61.

P.A. Samuelson (1947), Foundations of Economic Analysis. Cambridge, Mass.: Harvard University Press.

P.A. Samuelson (1987), "Sparks from Arrow's Anvil," in Feiwel (1987), ch. 3, pp. 154-178.

T.M. SCANLON (1987), "The Moral Basis of Interpersonal Comparisons," presented to the Sloan Conference on "Interpersonal Comparability of Welfare" at the University of California, Davis.

A. SChäFER AND R.W. Trapp (1989), "Distributional Equlity in Non-classical Utilitarianism - A Proof of Lerner's Theorem for 'Utilitarianism Incorporating Justice,", Theory and Decision, 26: 157-173.

F. SсHICK (1971), "Beyond Utilitarianism," Journal of Philosophy, 68: 657-666.

E. Schokkaert and B. Overlaet (1989), "Moral Intuitions and Economic Models of Distributive Justice," Social Choice and Welfare, 6: 19-31.

T. Schwartz (1970), "On the Possibility of Rational Policy Evaluation," Theory and Decision, 1: 89-106.

T. Schwartz (1975), "On the Utility of MacKay's Comparisons," Journal of Philosophy, 72: 549-551.

T. SchWARTZ (1979), "Welfare Judgments and Future Generations," Theory and Decision, 11: 181-194; reprinted in Brock (1979b). 
T. Seidenfeld, J.B. Kadane, and M.J. Schervish (1989), "On the Shared Preferences of Two Bayesian Decision Makers," Journal of Philosophy, 86: $225-244$.

C. SEIDL (1987), Review of Hagenaars (1986), Zeitschrift für Nationalökonomie, 47: $92-98$.

A.K. Sen (1969), "Planner's Preferences: Optimality, Distribution and Social Welfare," in Public Economics edited by J. Margolis and H. Guitton (London: Macmillan), ch. 8, pp. 201-221.

A.K. Sen (1970a), Collective Choice and Social Welfare. San Francisco: Holden-Day.

A.K. SEN (1970b, 1972), "Interpersonal Aggregation and Partial Comparability," and "A Correction," Econometrica, 38: 393-409 and 40: 959-960; reprinted in Sen (1982).

A.K. SEN (1973), On Economic Inequality. Oxford: Clarendon Press.

A.K. SEn (1974), "Rawls versus Bentham: An Axiomatic Examination of the Pure Distribution Problem," Theory and Decision, 4: 301-309; reprinted in N. Daniels (ed.) (1975) Reading Rawls: Critical Studies of "A Theory of Justice" (New York: Basic Books).

A.K. SEN (1977), "On Weights and Measures: Informational Constraints in Social Welfare Analysis," Econometrica, 45: 1539-72; reprinted in Sen (1982).

A.K. SEN (1978), "Ethical Measurement of Inequalities: Some Difficulties," in Personal Income Distribution edited by W. Krelle and A. Shorrocks (Amsterdam: North Holland; reprinted in Sen, 1982).

A.K. SEN (1979), "Interpersonal Comparisons of Welfare," in Economics and Human Welfare: Essays in Honor of Tibor Scitovsky edited by M.J. Boskin (New York: Academic Press), pp. 183-201; reprinted in Sen (1982). 
A.K. SEN (1980), "Equality of What?," in The Tanner Lectures on Human Values, Vol. I edited by S. McCurrin (Cambridge: Cambridge University Press; reprinted in Sen, 1982).

A.K. Sen (1982), Choice, Welfare and Measurement. Oxford: Basil Blackwell, and Cambridge, Mass.: MIT Press.

A.K. Sen (1984), "The Living Standard," Oxford Economic Papers, 36 (Supplement): $74-90$.

A.K. Sen (1985), Commodities and Capabilities. Amsterdam: North-Holland.

A.K. SEN (1986), "Social Choice Theory," in Handbook of Mathematical Economics, Vol. III edited by K.J. Arrow and M.D. Intriligator (Amsterdam: North-Holland), ch. 22, pp. 1073-1181.

A.K. SEN (1987a), On Ethics and Economics. Oxford: Basil Blackwell.

A.K. Sen et.al. (1987b), The Standard of Living. Cambridge: Cambridge University Press.

A.K. Sen And B. Williams (EDs.) (1982), Utilitarianism and Beyond. Cambridge: Cambridge University Press.

W.J. Shafer (1980), "On the Existence and Interpretation of Value Allocation," Econometrica, 48: 467-474.

L.S. Shapley (1969), "Utility Comparison and the Theory of Games," in La Décision: Agrégation et dynamique des ordres de préférence edited by G.Th. Guilbaud (Paris: Centre National pour la Recherche Scientifique).

C.L. Sheng (1987), "A Note on Interpersonal Comparisons of Utility," Theory and Decision, 22: 1-12.

C.L. Sheng (1989), "Some Quantitative Concepts of Value and Utility from a Utilitarian Point of View," Theory and Decision, 26: 175-195.

J.L. Simon (1974), "Interpersonal Welfare Comparisons Can be Made - and Used for Redistribution Decisons," Kyklos, 27: 63-98. 
J.L. Simon (1978), "Interpersonal Welfare Comparisons: A Reply," Kyklos, 31: 315-317.

A. Sмiтн (1759, revised 1790, reprinted 1975), The Theory of Moral Sentiments. Oxford: Clarendon Press.

R.A. Sorensen (1986), "Did the Intensity of My Preferences Double Last Night?," Philosophy of Science, 53: 282-285.

R.J. Stefanik (1981), "Harsanyi's Critical Rule Utilitarianism," Theory and Decision, 13: 71-80.

G.J. Stigler and G.S. Becker (1977), "De Gustibus Non Est Disputandum," American Economic Review, 67: 76-90.

S.S. Stevens (1966), "A Metric for the Social Consensus," Science, 151: 530-541.

S. Strasnick (1976a), "Social Choice and the Derivation of Rawls's Difference Principle," Journal of Philosophy, 73: 85-99.

S. Strasnick (1976b), "The Problem of Social Choice: Arrow to Rawls," Philosophy and Public Affairs, 5: 241-273.

S. STRASNICK (1977), "Ordinality and the Spirit of the Justified Dictator," Social Research, 44: 668-690.

S. Strasnick (1979), "Extended Sympathy Comparisons and the Basis of Social Choice," Theory and Decision, 10: 311-328.

R.H. Strotz (1958), "How Income Ought to Be Distributed: A Paradox in Distributive Ethics," Journal of Political Economy, 66: 189-205.

R.H. Strotz (1961), "How Income Ought to Be Distributed: Paradox Regained," Journal of Political Economy, 69: 271-278.

P. Suppes (1966), "Some Formal Models of Grading Principles," Synthese, 6: 284-306. 
P. Suppes And M. Winet (1955), "An Axiomatization of Utility Based on the Notion of Utility Differences," Management Science, 1: 259-270.

L.-G. Svensson (1985), "The Utilitarian Criterion, Finite Sensibility, and the Weak Majority Preference Principle: A Further Analysis," Social Choice and Welfare, 2: 23-35.

J. Tinbergen (1957), "Welfare Economics and Income Distribution," American Economic Review (Papers and Proceedings), 47: 490-503.

J. Tinbergen (1980), "Two Approaches to Quantify the Concept of Equitable Income Distribution," Kyklos, 33: 3-15.

J. Tinbergen (1985), Production, Income and Welfare: The Search for an Optimal Social Order. Lincoln, NE: University of Nebraska Press.

J. Tinbergen (1987a), "The Optimum Order Revisited," in Feiwel (1987), ch. 9, pp. 281-327.

J. Tinbergen (1987b), "The Tension Theory of Welfare," in Feiwel (1987), ch. 15 , pp. $410-417$.

L. Toharia (1978), "Interpersonal Welfare Comparisons and Welfare Economics: A Comment," Kyklos, 31: 311-314.

R.W. TRAPP (1989), “Utilitarianism Incorporating Justice' - A Decentralized Model of Ethical Decision Making," Erkenntnis (forthcoming),

W.S. VICKREY (1945), "Measuring Marginal Utility by Reactions to Risk," Econometrica, 13: 319-33.

W.S. Vickrey (1960), "Utility, Strategy and Social Decision Rules," Quarterly Journal of Economics, 74: 507-35.

W.S. Vickrey (1961), "Risk, Utility and Social Policy," Social Research, 28: 205-217; reprinted in Phelps (1973). 
I. Waldner (1972), "The Empirical Meaningfulness of Interpersonal Utility Comparisons," Journal of Philosophy, 69: 87-103.

I. WALdner (1974a), "Bare Preference and Interpersonal Utility Comparisons," Theory and Decision, 5: 313-328.

I. Waldner (1974b), "Value Neutrality," Theory and Decision, 5: 333-334.

V.C. Walsh (1964), "Discussion: The Status of Welfare Comparisons," Philosophy of Science, 31: 149-155.

P. WeIRICH (1983), "Utility Tempered with Equality," Nô̂s, 17: 423-439.

P. WeIrich (1984), "Interpersonal Utility in Principles of Social Choice," Erkenntnis, 21: 295-317.

B. Williams (1985), Ethics and the Limits of Philosophy. London: Fontana Press/Collins.

D. Wittman (1974), "Punishment as Retribution," Theory and Decision, 4: 209-237.

D. Wittman (1979), "A Diagrammatic Exposition of Justice," Theory and Decision, 11: 207-237; reprinted in Brock (1979b).

M.E. YAARI (1981), "Rawls, Edgeworth, Shapley, Nash: Theories of Distributive Justice Re-examined," Journal of Economic Theory, 24: 1-39.

M.E. YaAri And M. Bar-Hillel (1984), "On Dividing Justly," Social Choice and Welfare, 1: 1-24. 


\section{Working Papers of the Department of Economics Published since 1989}

$89 / 370$

B. BENSAID/R.J. GARY-BOBO/

S. FEDERBUSCH

The Strategic Aspects of Profit Sharing in the Industry

$89 / 374$

Francisco S. TORRES

Small Countries and Exogenous Policy Shocks

$89 / 375$

Renzo DAVIDDI

Rouble Convertibility: A Realistic Target

89/377

Elettra AGLIARDI

On the Robustness of Contestability Theory

$89 / 378$

Stephen MARTIN

The Welfare Consequences of Transaction Costs in Financial Markets

\section{$89 / 381$}

Susan SENIOR NELLO

Recent Developments in Relations Between the $\mathrm{EC}$ and Eastem Europe

\section{$89 / 382$}

Jean GABSZEWICZ/ Paolo GARELLA/

Charles NOLLET

Spatial Price Competition With Uninformed Buyers

\section{$89 / 383$}

Benedetto GUI

Beneficiary and Dominant Roles in Organizations: The Case of Nonprofits

\section{$89 / 384$}

Agustín MARAVALL/ Daniel PEÑA Missing Observations, Additive Outliers and Inverse Autocorrelation Function

$89 / 385$

Stephen MARTIN

Product Differentiation and Market Performance in Oligopoly

\section{$89 / 386$}

Dalia MARIN

Is the Export-Led Growth Hypothesis Valid for Industrialized Countries?
89/387

Stephen MARTIN

Modeling Oligopolistic Interaction

$89 / 388$

Jean-Claude CHOURAQUI

The Conduct of Monetary Policy: What have we Learned From Recent Experience

$89 / 390$

Corrado BENASSI

Imperfect Information and Financial Markets: A General Equilibrium Model

$89 / 394$

Serge-Christophe KOLM

Adequacy, Equity and Fundamental Dominance: Unanimous and Comparable Allocations in Rational Social Choice, with Applications to Marriage and Wages

$89 / 395$

Daniel HEYMANN/ Axel LEIJONHUFVUD

On the Use of Currency Reform in Inflation Stabilization

$89 / 400$

Robert J. GARY-BOBO

On the Existence of Equilibrium Configurations in a Class of Asymmetric Market Entry Games

$89 / 402$

Stephen MARTIN

Direct Foreign Investment in The United States

$89 / 413$

Francisco S. TORRES

Portugal, the EMS and 1992: Stabilization and Liberalization

\section{$89 / 416$}

Joerg MAYER

Reserve Switches and Exchange-Rate Variability: The Presumed Inherent Instability of the Multiple Reserve-Currency System

$89 / 417$

José P. ESPERANÇA/ Neil KAY

Foreign Direct Investment and Competition in the Advertising Sector: The Italian Case

$89 / 418$

Luigi BRIGHI/ Mario FORNI

Aggregation Across Agents in Demand Systems 
$89 / 420$

Corrado BENASSI

A Competitive Model of Credit Intermediation

$89 / 422$

Marcus MILLER/ Mark SALMON

When does Coordination pay?

$89 / 423$

Marcus MILLER/ Mark SALMON/

Alan SUTHERLAND

Time Consistency, Discounting and the Returns to Cooperation

$89 / 424$

Frank CRITCHLEY/ Paul MARRIOTT/

Mark SALMON

On the Differential Geometry of the Wald Test with Nonlinear Restrictions

$89 / 425$

Peter J. HAMMOND

On the Impossibility of Perfect Capital Markets

$89 / 426$

Peter J. HAMMOND

Perfected Option Markets in Economies with Adverse Selection

$89 / 427$

Peter J. HAMMOND

Irreducibility, Resource Relatedness, and Survival with Individual Non-Convexities

ECO No. 90/1

Tamer BAŞAR and Mark SALMON

Credibility and the Value of Information

Transmission in a Model of Monetary Policy and Inflation

ECO No. $90 / 2$

Horst UNGERER

The EMS - The First Ten Years

Policies - Developments - Evolution

ECO No. 90/3

Peter J. HAMMOND

Interpersonal Comparisons of Utility: Why and how they are and should be made

ECO No. 90/4

Peter J. HAMMOND

A Revelation Principle for (Boundedly) Bayesian

Rationalizable Strategies

ECO No. $90 / 5$

Peter J. HAMMOND

Independence of Irrelevant Interpersonal

Comparisons

- Please note: As from January 1990, the EUI Working Papers Series is divided into six subseries, each series will be numbered individually (e.g. EUI Working Paper LAW No 90/1).
ECO No. $90 / 6$

Hal R. VARIAN

A Solution to the Problem of Externalities and Public Goods when Agents are Well-Informed

ECO No. 90/7

Hal R. VARIAN

Sequential Provision of Public Goods

ECO No. $90 / 8$

T. BRIANZA, L. PHLIPS and J.F. RICHARD Futures Markets, Speculation and Monopoly Pricing 


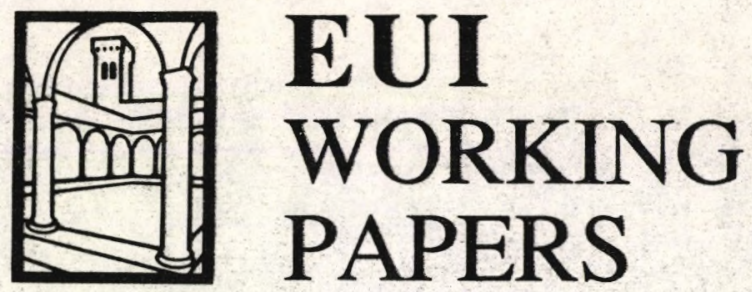

EUI Working Papers are published and distributed by the European University Institute, Florence

Copies can be obtained free of charge - depending on the availability of stocks - from:

The Publications Officer

European University Institute

Badia Fiesolana

I-50016 San Domenico di Fiesole (FI)

Italy

Please use order form overleaf 


\title{
Publications of the European University Institute
}

To

\author{
The Publications Officer \\ European University Institute \\ Badia Fiesolana \\ I-50016 San Domenico di Fiesole (FI) \\ Italy
}

From $\quad$ Name $\ldots \ldots \ldots \ldots \ldots \ldots$

Address . . . . . . . . . . .

$\square$ Please send me a complete list of EUI Working Papers

$\square$ Please send me a complete list of EUI book publications

$\square$ Please send me the EUI brochure Academic Year 1990/91

Please send me the following EUI Working Paper(s):

No, Author

Title:

No, Author

Title:

No, Author

Title:

No, Author

Title:

Date

Signature 
89/384

Agustín MARAVALL/

Daniel PEÑA

Missing Observations, Additive

Outliers and Inverse Auto-

correlation Function

$89 / 385$

Stephen MARTIN

Product Differentiation and

Market Performance in Oligopoly

$89 / 386$

Dalia MARIN

Is the Export-Led Growth

Hypothesis Valid for

Industrialized Countries?

89/387

Stephen MARTIN

Modeling Oligopolistic Interaction

$89 / 388$

Jean-Claude CHOURAQUI

The Conduct of Monetary Policy:

What have we Learned From

Recent Experience

$89 / 389$

Léonce BEKEMANS

Economics in Culture vs. Culture in Economics

$89 / 390$

Corrado BENASSI

Imperfect Information and

Financial Markets: A General

Equilibrium Model

\section{$89 / 391$}

Patrick DEL DUCA

Italian Judicial Activism in Light

of French and American

Doctrines of Judicial Review and

Administrative Decisionmaking:

The Case of Air Pollution
89/392

Dieter ZIEGLER

The Bank of England in the

Provinces: The Case of the

Leicester Branch Closing, 1872

\section{9/393}

Gunther TEUBNER

How the Law Thinks:

Toward a Constructivist

Epistemology of Law

\section{$89 / 394$}

Serge-Christophe KOLM Adequacy, Equity and

Fundamental Dominance:

Unanimous and Comparable

Allocations in Rational Social

Choice, with Applications to

Marriage and Wages

$89 / 395$

Daniel HEYMANN/

Axel LEIJONHUFVUD

On the Use of Currency Reform

in Inflation Stabilization

\section{9/396}

\section{Gisela BOCK}

Challenging Dichotomies:

Theoretical and Historical

Perspectives on Women's Studies in the Humanities and Social Sciences

\section{9/397}

Giovanna C. CIFOLETTI

Quaestio sive aequatio:

la nozione di problema nelle

Regulae

$89 / 398$

Michela NACCI

L'équilibre difficile. Georges

Friedmann avant la sociologie du travail 
89/399

Bruno WANROOIJ

Zefthe Akaira, o delle identità smarrite

$89 / 400$

Robert J. GARY-BOBO

On the Existence of Equilibrium

Configurations in a Class of

Asymmetric Market Entry Games

\section{$89 / 401$}

Federico ROMERO

The US and Western Europe:

A Comparative Discussion of

Labor Movements in the Postwar

Economy

$89 / 402$

Stephen MARTIN

Direct Foreign Investment in the United States

\section{$89 / 403$}

Christine LAMARRE

La vie des enfants et des vieillards assistés à Dijon au $18^{\mathrm{e}}$ siècle

$89 / 404$

Christian JOERGES

Product liability and product

safety in the European

Community

\section{$89 / 405$}

Giandomenico MAJONE

Regulating Europe:

Problems and Prospects

\section{9/406}

Fabio SDOGATI

Exchange Rate Fluctuations and the Patterns of International Trade: A Study of the Flow of

Trade from Newly Industrialized

Countries to the European

Community at the Industry Level

89/407

Angela LIBERATORE

EC Environmental Research and EC Environmental Policy:

A study in the utilization of knowledge for regulatory purposes

$89 / 408$

J.-Matthias Graf von der

SCHULENBURG

Regulation and Deregulation of Insurance Markets in the Federal Republic of Germany

$89 / 409$

Greg KASER

Acceptable Nuclear Risk: Some

Examples from Europe

$89 / 410$

Léonce BEKEMANS/Manfred

GLAGOW/Jeremy MOON

Beyond Market and State

Alternative Approaches to

Meeting Societal Demands

$89 / 411$

Erich KAUFER

The Regulation of Drug

Development: In Search of a Common European Approach 
$89 / 412$

Gianna GIANNELLI/

Gøsta ESPING-ANDERSEN

Labor Costs and Employment in the Service Economy

\section{$89 / 413$}

Francisco S. TORRES

Portugal, the EMS and 1992:

Stabilization and Liberalization

\section{$89 / 414$}

Gøsta ESPING-ANDERSEN/

Harald SONNBERGER

The Demographics of Age in

Labor Market Management

\section{$89 / 415$}

Fritz von NORDHEIM NIELSEN

The Scandinavian Model:

Reformist Road to Socialism or

Dead End Street?

\section{$89 / 416$}

\section{Joerg MAYER}

Reserve Switches and Exchange-

Rate Variability: The Presumed

Inherent Instability of the Multiple

Reserve-Currency System

\section{$89 / 417$}

José P. ESPERANÇA/Neil KAY

Foreign Direct Investment and

Competition in the Advertising

Sector: The Italian Case

\section{$89 / 418$}

Luigi BRIGHI/Mario FORNI

Aggregation Across Agents in

Demand Systems
$89 / 419$

Hans Ulrich JESSURUN d'OLIVEIRA

Nationality and Apartheid: Some

Reflections on the Use of

Nationality Law as a Weapon against Violation of Fundamental Rights

$89 / 420$

Corrado BENASSI

A Competitive Model of Credit Intermediation

$89 / 421$

Ester STEVERS

Telecommunications Regulation in the European Community: The Commission of the European

Communities as Regulatory Actor

$89 / 422$

Marcus MILLER/Mark SALMON When does Coordination pay?

$89 / 423$

Marcus MILLER/Mark

SALMON/

Alan SUTHERLAND

Time Consistency, Discounting and the Returns to Cooperation

$89 / 424$

Frank CRITCHLEY/Paul

MARRIOTT/Mark SALMON

On the Differential Geometry of the Wald Test with Nonlinear

Restrictions

$89 / 425$

Peter J. HAMMOND

On the Impossibility of Perfect

Capital Markets 
$89 / 426$

Peter J. HAMMOND

Perfected Option Markets in

Economies with Adverse Selection

$89 / 427$

Peter J. HAMMOND

Irreducibility, Resource

Relatedness, and Survival with

Individual Non-Convexities

$89 / 428$

Joanna GOYDER

"Business Format" Franchising

and EEC Competition Law 


\section{EUI Working Papers as from 1990}

Please note: As from January 1990, the EUI Working Papers Series is divided into six sub-series, each series will be numbered individually (e.g. EUI Working Paper LAW No 90/1).

\section{Working Papers in Law}

LAW No 90/1

David NELKEN

The Truth about Law's Truth
LAW No 90/2

Antonio CASSESE/Andrew

CLAPHAM/Joseph H.H. WEILER

1992 - What are our Rights?

Agenda for a Human Rights

Action Plan

\section{Working Papers of the European Policy Unit}

\section{EPU No 90/1}

Renaud DEHOUSSE/Joseph H.H.

WEILER

EPC and the Single Act:

From Soft Law to Hard Law? 


\section{Working Papers in Economics}

ECO No. 90/1

Tamer BAŞAR/Mark SALMON

Credibility and the Value of

Information Transmission in a

Model of Monetary Policy and

Inflation

ECO No. 90/2

Horst UNGERER

The EMS - The First Ten Years

Policies - Developments -

Evolution

ECO No. 90/3

Peter J. HAMMOND

Interpersonal Comparisons of

Utility: Why and how they are

and should be made

ECO No. 90/4

Peter J. HAMMOND

A Revelation Principle for

(Boundedly) Bayesian

Rationalizable Strategies

ECO No. 90/5

Peter J. HAMMOND

Independence of Irrelevant

Interpersonal Comparisons

ECO No. 90/6

Hal R. VARIAN

A Solution to the Problem of

Externalities and Public Goods

when Agents are Well-Informed

ECO No. 90/7

Hal R. VARIAN

Sequential Provision of Public

Goods
ECO No. 90/8

T. BRIANZA/L. PHLIPS/J.-F. RICHARD

Futures Markets, Speculation and Monopoly Pricing 


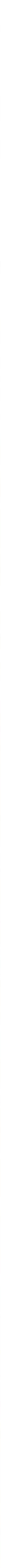


